University of Louisville

ThinkIR: The University of Louisville's Institutional Repository

Electronic Theses and Dissertations

$5-2017$

\title{
Labor and happiness.
}

Tyler Reid Madden

University of Louisville

Follow this and additional works at: https://ir.library.louisville.edu/etd

Part of the Theatre and Performance Studies Commons

\section{Recommended Citation}

Madden, Tyler Reid, "Labor and happiness." (2017). Electronic Theses and Dissertations. Paper 2657.

https://doi.org/10.18297/etd/2657

This Master's Thesis is brought to you for free and open access by ThinkIR: The University of Louisville's Institutional Repository. It has been accepted for inclusion in Electronic Theses and Dissertations by an authorized administrator of ThinkIR: The University of Louisville's Institutional Repository. This title appears here courtesy of the author, who has retained all other copyrights. For more information, please contact thinkir@louisville.edu. 


\title{
LABOR AND HAPPINESS
}

\author{
By \\ Tyler Reid Madden \\ B.F.A., North Carolina A\&T State, 2013
}

\begin{abstract}
A Thesis
Submitted to the Faculty of the Colleges of Arts and Sciences of the University of Louisville In Partial Fulfillment of the Requirements for the Degree of
\end{abstract}

Master of Fine Arts in Theatre Arts

\author{
Department of Theatre Arts \\ University of Louisville \\ Louisville, Kentucky
}

May 2017 
Copyright 2017 by Tyler Reid Madden

All rights reserved 



\section{LABOR AND HAPPINESS}

\section{By}

Tyler Reid Madden

B.F.A., North Carolina A\&T State, 2013

A Thesis Approved on

April 26, 2017

by the following Thesis Committee:

Professor Johnny Jones

Dr. Baron Kelly

Dr. Siobhan Smith 


\section{DEDICATION}

This thesis or dissertation is dedicated to my parents

Letitia Madden and Ron Corbett. Sr.

I also want to dedicate my thesis to my

Stepmom, Denean Corbett, for accepting me as her own.

Next I want to dedicate my thesis and my process to

my girlfriend Raven Foust

for being my "day one" through this process.

Thank you for being patient with me in this journey.

Lastly, I want to dedicate this thesis to my late Grandfather, Raymond Madden Sr.

Thank you for being a male figure in my life

Love you, always. 


\section{ACKNOWLEDGMENTS}

I would like to thank my major professor chair, Nefertiti Burton for being supportive in my process, always being the source for optimism. I would like to thank my thesis committee: Dr. Baron Kelly, for not only serving as a part of my thesis committee, but for being a mentor and not letting me settle for mediocrity in my craft. Professor Johnny Jones, for being patient and being a guide throughout this process, I cannot thank you enough man. I want to thank Dr. Siobhan Smith for being on board with me on this thesis, I know you had a busy schedule but you were willing to work with me and I thank you for that.

I would also like to thank my past and present professors: Carol Stewart, Daniel Hill, Dr. Amy Steiger, Ashley Smith, Erin Crites, Rachel Hillmer, Dr. Jenn Calvano, Dr. Janna Segal, Zan Sawyer-Daily, Dr. Russ Vandenbrouke, Miller Lucky. Jr, Donna Bradby, Tina Liggins, Dr. Vanita Vactor, Greg Horton, and the late Frankie Day. I want to thank the first and second years: Ross Shenker, Mia Rocchio, Lois Abdelmalek, Sidney Edwards, Lauren Dobbs, Terry Tocantins, and Lashondra Hood. Lastly, I want to thank the best classmates that a man can ask for: Paula Lockhart, Shaleen Cholera, and Danielle Smart, I love you guys so much, thank you for making this an enjoyable experience.

WE MADE IT! 


\section{ABSTRACT LABOR AND HAPPINESS \\ Tyler Reid Madden}

April 26, 2017

This thesis reflects my process and my development of performing as Troy Maxson in August Wilson's Fences. I will be exploring the parallels that I have found on the concept of labor, between the history of labor as a black man in America and the labor of an actor. More specifically, I will be explaining my process in finding happiness in my own laboring process of building a character. This is also an exploration of how I transformed myself from a 29-year-old black man to a 53-year-old black man. Also, transitioning from a black man in the 21 st century, to a black man who was born in the early 1900's and lived in the 1950's. 


\section{TABLE OF CONTENTS}

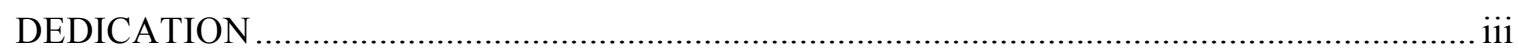

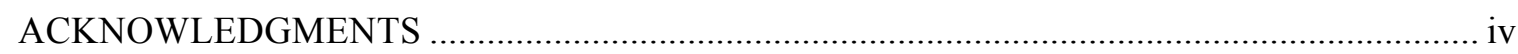

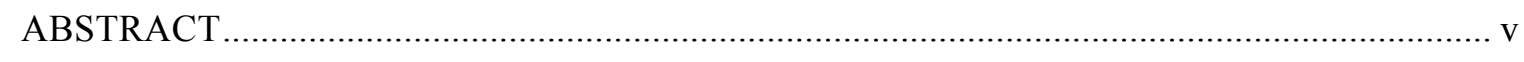

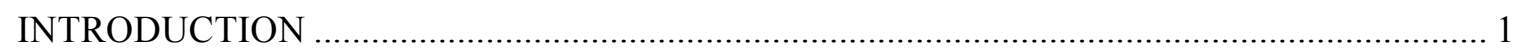

SECTION ONE: THE BEGINNING'S OF A LABORER …..................................................... 3

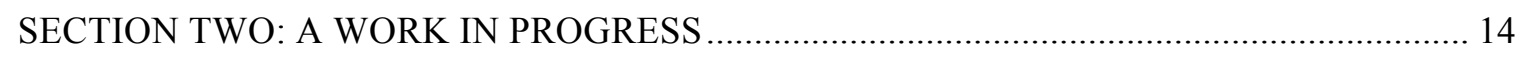

SECTION THREE: OH...TO BE TROY MAXSON: THE LABOR OF CREATING TROY

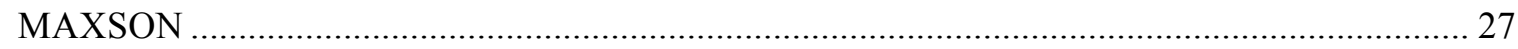

SECTION FOUR: ENJOYING THE FRUITS OF YOUR LABOR ......................................... 53

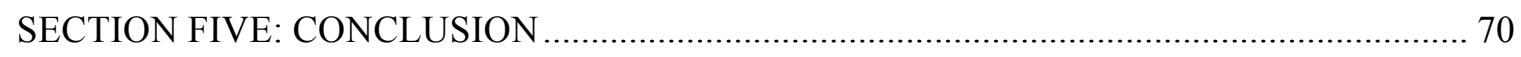

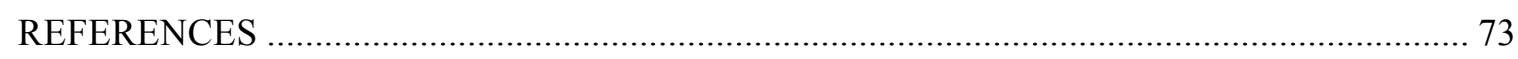

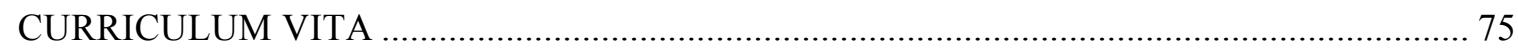




\section{INTRODUCTION}

There is always some kind of process of labor in our lives. However, is there always joy in the work that we do? As a child, even as a young adult, we can clearly see the joy in knowing that you can do the basic things like walking and talking. We celebrate when we accomplish something that we are working towards. The result of this working towards is a product. To connect this idea to adulthood, the product of the work is when a person can provide for themselves and possibly for others. Although the legal age of adulthood is eighteen, the Fair Labor Standards Act states the legal age for a person to start working is fourteen. ${ }^{1}$ If you could ask the protagonist, Troy Maxson from August Wilson's iconic play Fences, he might tell you that working towards a product begins as soon as you were learning how to walk.

This thesis is about my process of creating a character that claims to have done nothing but work his entire life. Troy Maxson, a 53-year-old black man who expresses feeling trapped under the hardships of blacks in 1950's America. Through this process, not only was I discovering what it meant to work hard all your life as a black man in the 1950's, but I was also discovering what it means to labor as an actor. This thesis represents a bookend to my college career, while simultaneously representing a new chapter in my career. This thesis is a reflection of the labor it takes to be an actor, while examining the labor of an oppressed black man in the 1950 's. It takes a lot of work to be an actor, which is something that I feel is overlooked from people who have never acted before. In this thesis, I want to further emphasize the labor of acting

\footnotetext{
1 "Fair Labor Standards Act Advisor ". Ed. Labor, United States Department of.
} 
by also showing the discoveries that informed me of my character's behavior. However, I cannot bring up all these aspects of labor without talking about my desire for acting. I have dreams of being on stage all the time. And I want to focus on how I am making that dream come true. Dreams are a part of life, but without work those dreams will never become a reality. I cannot say that I have enjoyed my whole process of becoming an actor. The work of constantly striving for perfection can be very difficult and demoralizing, I sometimes it felt like a dream deferred. My need for perfection made me begin to question my life work as an actor. When does one enjoy the fruits of his labor? Or, does he enjoy it at all? Attending the University of Louisville to seek my MFA made me realize that in order to become the actor I wanted to be, I would have to learn to love the labors and processes that would get me there. In this thesis, I will discuss these topics through my process of creating the character, Troy Maxson, in Fences. 


\section{SECTION ONE}

\section{THE BEGINNING'S OF A LABORER}

"You go on and get your book-learning so you can work yourself up in that A\&P or learn how to fix cars or build houses or something, get you a trade. That way you have something can't nobody take away from you.", 2

\section{My First Model of a Black Male Laborer}

The first time I learned how to earn a dollar was when I was 10 years old. My grandfather, who was a concrete foreman, gave me an opportunity to earn money by letting me cut his grass on Saturdays. While I was making money, I was simultaneously getting to know the man who would influence me for the rest of my life. My grandfather, Raymond Madden, was a model of a black male laborer the same way I thought Troy was to his son, Cory Maxson, in Fences. My grandfather was a stern man, but also a proud man who loved what he stood for as a black man. Most of the lessons that he taught me were lessons that I learned from just watching him, how he handled himself, and how others treated him. Just as Troy Maxson is described in opening stage directions of the play, my grandfather was also someone you could describe as "bigger than life." ${ }^{33}$ He had a noticeably natural presence. This is something that I always looked up to. The most compelling thing about my grandfather was his work ethic. I always wondered how a man could work a job that required a vast amount of labor; he did this until his sudden death at age 65. My grandfather would get up early to work his shift from 9 a.m. and would not come home until 9 p.m., working those twelve hours for five days a week. I vividly remember

\footnotetext{
${ }^{2}$ Wilson, August. Fences 1986 ed. New York, New York U.S.A. : Samuel French, 1986. Print. (pg. 37)

${ }^{3}$ Bogumil, Mary L. Understanding August Wilson Revised ed. Columbia, SC USA University of South Carolina Press 2011. Print. (pg. 43)
} 
watching my grandfather come in the house with concrete and dirt coating the soles of his construction boots. He was tired but he was standing tall as if that whole day of work had not conquered him. I really wanted to be like him; he showed grit that was impossible to tear down, even when he was dealing with kidney failure a year before his death. It took me a while to understand what could make a man get up the next day and do the same thing for five days straight. What I realize is what pushed my grandfather to do it everyday was the satisfaction in knowing he worked for something. There is a line from Fences that comes to mind when I think about working for something. When Troy is talking to his older son Lyons, a struggling musician, Troy explains the importance of working for yourself and not depending on others for anything:

"You still trying to get something for nothing. Life don't owe you nothing you owe it to yourself." ${ }^{4}$ My grandfather understood this, and it helped me to understand that it was about working for what you want instead of depending on others to get it for you. Despite this image of my grandfather as a laborer, I still did not unde rstand how he became so respected by others that worked with him. That particular lesson did not come until I was 19 years old, when I was working

\footnotetext{
${ }^{4}$ Fences Pg. 22
} 


\section{Initiative and the workplace}

Before I attended North Carolina A\&T State University (NC A\&T), I worked s everal jobs after graduating from high school. It was at this time in my life that I started to develop my own experiences as a laborer. At this time, I had worked three jobs within a span of three years, One of those jobs was working at a car dealership called Terry Labonte Chevrolet where I was a minor automotive technician. Initially, since I had no automotive experience, I only vacuumed the cars and put oil change stickers on the windshields while the other mechanics worked on the cars. Eventually, I wa s taught how to work on the cars and soon I was handling routine car maintenances such as oil changes, tire rotations, filling up the fluids, and checking the tire pressures. This was the beginning of me learning my first trade. I felt as if I was gaining respect around the shop, but eventually my supervisor, Hank Thompson, corrected me. Hank became my second model of what a laboring man looked like. Like my grandfather, Hank had a managerial position, which later on supported the lesson that I learned from him. Hank is a man who has lived a life that I could not imagine. He is a white man who is well in his 60 's with just a middle school education. At the dealership, he had a reputation for being "a hard ass," particularly to people under his authority. One day at work, after a morning rush of cars that came into the shop, my work ethic came up in a conversation with Hank. I insisted that Hank believed I was a good worker. However, he told me, “Tyler, you're a good worker, but you lack initiative.” I felt baffled because I did not know how to interpret what he was saying. Then he pointed around the shop of all things that I could be doing, while I was waiting on a car to come into the shop. After I left work, I searched for the definition of initiative: 
1 the ability to assess and initiate things independently: use your initiative, imagination, and common sense

2. [in singular] the power or opportunity to act or take charge before others do: we have lost the initiative and allowed our opponents to dictate the subject. 5

The definition contains the root word "initiate", which means "to cause a process or action to begin. ${ }^{\prime 6}$ After reviewing the definition of initiative, the important words or phrases that jumped out to me were: “opportunity", "independent", and "take charge". What my manager was trying to teach me was that I should not wait on the opportunity for work to come, but I must independently find the work. After that day, my attitude and approach to being a part of the labor force changed. I took charge more at work, became a leader, became more helpful, and began to find ways to make better use of my time. Instead of demanding gratification for my efforts, I earned my gratification in the form of a pay raise.

After my career at the dealership, I approached college with the same mentality. I tried to find ways to let my personal experiences inform or inspire my work. Portraying Troy Maxson inspired me to pull these experiences from my own life to further connect with my character, particularly when it comes to labor. Troy is a black man living in the 1950's during a time where blacks were being discriminated against in a predominantly segregated America. In one scene, Troy was talking to his best friend, Bono, about confronting their supervisor about his position as a garbage collector. Instead of driving the trucks, Troy and Bono's job was to dump the garbage

\footnotetext{
${ }^{5}$ New Oxford American Dictionary: Oxford University Press, Inc, 2010, 2016. Print. See Initiative

${ }^{6}$ New Oxford American Dictionary: Oxford University Press, Inc, 2010, 2016. Print. See Initiate
} 
in the truck. Instead of settling, Troy took the initiative to say something to his supervisor, which later propelled him to a promotion as the first African American driver. This was profound for me, because the two labor models that I have always followed were in respectable positions at their jobs like Troy. The only concern I had was that I could not find something that I enjoyed doing. Even though I learned how to become a better laborer, I did not have anything that I was passionate about that was worth committing to. That did not happen until I went to NC A\&T and I rediscovered my passion for acting. 


\section{What made me want to act}

Although my inspiration for acting came earlier in my life, I did not capitalize on this discovery until I began pursuing my undergraduate degree. As a kid, I was full of imagination and curiosity. Now, as an adult, I cannot stress enough to others in my field how important it is for us as a society to invest in the imagination of a child. We teach kids how to structure their lives as an adult, but we forget to remind them that their imagination is also important for creativity. It is important to keep and harness that kind of imagination as an adult, especially for an actor. Robert Cohen, a theatre practitioner and founder of the Drama program at the University of California at Irvine, talks about the importance of imagination in his textbook Acting One/Acting Two. In Chapter 20, "Imagination and Creativity", Cohen begins with the following statement:

"Imagination is the wellspring of the acting impulse." He expounds more on the topic of imagination, by stating that imagination is the initiative of an actor's goal when they are acting, but that "the characters goal must also reflect the character's fantasy, the character's dream, the character's imagined future." 8 When I read this, I instantly thought about my childhood and what made me invest in my imagination in my adult life.

When I was 11 years old, I met this kid in my neighborhood in the most unusual way. I was playing with some friends of mine when I saw this kid named Gogo running around the apartment complex where I lived. While his playful behavior was normal, his costume from the

\footnotetext{
${ }^{7}$ Cohen, Robert. Acting One/ Acting Two 5th ed. New York, NY McGraw-Hill/ Chris Freitag 2008. Print. (pg. 158)

${ }^{8}$ Ibid.
} 
cartoon, Teenage Mutant Ninja Turtles was not. This costume consisted of a turtle shell to go on his back and a chest piece that looked like the chest of a turtle, a red bandana around his forehead, and a plastic sword in his hand. My friends and I looked at him weirdly and proceeded to laugh at him. What I could not see or understand was that Gogo was exploring his imagination freely, or as Cohen would define it, he was exploring his "visions of adventure." 9 The irony of all this is that a couple of weeks later, I started to explore my "visions of adventure" 10 by dressing up as Zorro after I watched the movie, The Mask of Zorro. Even though this was a great discovery, I still did nothing to further explore it until I made the decision to do theatre when I went to NC A\&T.

The day I decided to do theatre was just a couple days after I almost fathered a child. I was dating a girl whom I have only known for approximately three months, and I got her pregnant after less than a month of dating her. The relationship ended when we both agreed on getting an abortion, which is one of my biggest regrets because I have always felt that I wanted the abortion for selfish reasons. However, that decision revealed to me that I did not know what I wanted to do with my life. At 23 years old and only two years of school completed, I had not declared a major, which was symbolic of the lack of seriousness I had for school. During a meeting with my advisor, she reminded me how excited I was about acting and how I had taken an Acting for Non-Majors class. My initial reservations about being a theatre major were based on my mother's thoughts that theatre would not be a good fit for me. When I talked to my advisor she asked plainly, "Is your mother paying for your financial aid to go to school." I told her no.

\footnotetext{
${ }^{9}$ Ibid.

${ }^{10}$ Ibid
} 
After that meeting, I met with the person who would become my advisor in the theatre arts department, and I declared my major. Ironically, that eventful day watching Gogo when I was 11 years old came full-circle for me, as I discovered that he was currently a theatre major at NC A\&T as well. What I learned from this experience is that you can have initiative, but you have to invest your energy into something fulfilling. Ever since I was child I have always had an imagination, but I never actively explored my imagination with something fulfilling. When I started to act, it gave me the platform to explore my imagination. 


\section{For real, Not for Play: Becoming a Believable Actor}

During my second year in the the atre program at NC A\&T, I was asked a question from one of my acting professors, Miller Lucky. He asked us individually what was the most important thing we wanted to enhance in our acting, and my answer was to be as real as possible. The most compelling thing for me about watching talented actors was their ability to become very convincing in their portrayals. Uta Hagen, a renowned pioneer amongst the world of theatre and acting, talks about acting and being convincing on stage in her book Respect for Acting. In one of her chapters entitled "Reality", She simply states:

We have to open all our senses and innermost feelings to the extra ordinary realities of existence. We have to receive these realities with innocence and freshness, as though we had just been born. To create, one has to take known elements and make something new of them, and as we have only a few hours of compressed life on stage, our creation better count. $^{11}$

I invested in this part of acting. I believe that actors must submerge themselves in a role without it taking over their own sanity. Although I was passionate about being believable on stage, I had difficulties in figuring out how to connect to my characters in that way. This was a hindrance until I came across two important elements that helped me in this process: substitution and empathy. According to Hagen, substitution is "using our own experiences and remembrances, through the use of imaginative extension of realities, and putting them in the place of the fiction

${ }^{11}$ Hagen, Uta. Respect for Acting New York John Wiley \& Sons, Inc 1973, 2008. Print. (pg. 75) 
of the play."12 The purpose of substitution is to trigger an emotional response. As a young actor this was necessary to understand and strive to achieve, because for a person who had no acting experience I had no idea how to tap into a character's circumstances truthfully. Subsequently, this brings me to my next valuable element that I learned: empathy.

How I learned empathy was unique, because it was taught to me in a restaurant. I was working as a server in a restaurant when I came across a customer who was involved in theatre. He asked me what I was in school for, and I told him I was in the theatre arts program at NC A\&T. He was inclined to tell me that he was a director, which brought up a long discussion on acting. Before we ended our discussion, he told me that one of the major components to acting is empathy. According to the New Oxford American Dictionary, empathy is "the ability to understand and share the feelings of another." ${ }^{\prime 3}$ Cohen talks about empathy, from the audience perspective and why it is important:

Audience empathy, in fact, comes almost entirely from the audience's identification with the character's expectations. ${ }^{14}$

The way I interpreted this is that the audience responds to the characters trying to achieve their goals through the play, whether they obtain the goal or not. It is the inner and external turmoil of the character working through their obstacles to achieve that goal that the audience identifies with. For instance, watching Troy struggle to tell Rose about his infidelity, the audience

\footnotetext{
${ }^{12}$ Hagen, Pg. 34.

${ }^{13}$ New Oxford American Dictionary: Oxford University Press, Inc, 2010, 2016. Print. See empathy

${ }^{14}$ Cohen, Pg.53.
} 
anticipates or want to know what is going to come next. This makes the audience more invested in the characters.

I wish I could remember the gentleman's name, because he changed my whole spectrum on acting. I realized that in order for me to be someone else I had to care about someone other than myself. Obtaining empathy was not a quick lesson, but it instead informed a process of maturation for me. It taught me to treat the characters as real people. Of course, characters are fictional or constructed, but their circumstances stem from real life experiences. The root of empathy is feelings, which is why as a tradition before I go on stage to perform I always say a prayer, not just for myself, but also for the ability to tell my character's story truthfully. I pray for my character like I pray for real people.

My place in the working class has been and still is a manifestation. I was lucky to have found something that I was passionate about and I would like to spend the rest of my life doing. Most of my family had never had the chance to find the initiative to do something that they wanted to do, or had many options granted to them. I was also lucky to find people that cared enough to invest their time and effort in my maturation as a laborer. This portion of my life as a laborer was only the commencement of what I now consider today as my job description, and that is being a working actor. 


\title{
SECTION TWO
}

\author{
A WORK IN PROGRESS \\ "Look here, Rose ... Mr. Rand called me into his office today when I got back from talking to \\ them people down there ... it come from up top ... he called me in and told me they was making \\ me a driver. ", 15
}

\section{Overcoming my Weakness Through my Strength}

My journey of becoming a working actor was not easy. During my years in undergrad, one of the biggest obstacles I faced was my enunciation. I have a history of speech problems and had to take an additional speech class from kindergarten through middle school. My speech became manageable, but it was not perfect. It was not until I took my first acting class in the NC A\&T program that I realized that I needed additional work on my enunciation.

During my first week of class, my chair professor Frankie Day, asked my classmates and I to come in with a prepared monologue for our next class. I chose a monologue from the movie $A$ Time to Kill, which was my first mistake. It is a common rule not to do movie monologues in theatre. However, it was one of my favorite scenes and I already knew the monologue very well. The next day, after I performed the monologue in class, I felt very confident that my chair professor would love my performance. Unfortunately, despite the confidence, my chair professor said that she could not understand me. Instead of enunciating my words and speaking with clarity, I had mumbled through the entire monologue. In that moment, I realized that I needed to dedicate more time to my enunciation so my audiences could understand me.

\footnotetext{
${ }^{15}$ Fences, Pg. 44.
} 
Although my education at NC A\&T had been fruitful, some of the training was inadequate. For example, when I would perform, whether it was on stage or in class, the professor or direc tor would always tell me to "hit" my consonants or to improve my diction. I was given these notes without being taught how to improve in these areas. Cohen explains the importance of an actor to have good diction:

Good diction has long been considered es sential to acting, primarily so that the actor can be clearly heard and understood throughout the theatre and can make the most of the author's words and the character's verbal tactics, wit, and persuasive authority. ${ }^{16}$

Not only do I have to be audible, but I also have to make sense of the character and the playwright's words. Whenever I was given those notes, it went without being taught how to improve in those areas. Because of that, when I was in a performance, I would concentrate so much on my "T", "P", and "C" sounds that I would forget the complete value of the words, including the vowels or the actual meaning of the words. What I needed was a technique, and I did not have the necessary tools to develop one.

My strength in acting has always been my ability to move naturally on stage. My stage movement was not based on any acting technique, but was instead discovered mostly from dancing. My movement professor at NC A\&T, Mrs. Tina Liggins, was exceptional as a movement teacher because of her background in dance. I was never considered a dancer until I met Mrs. Tina. When I was at NC A\&T, we did one major musical, Langston Hughes’ Black Nativity, which served as our most profitable show of the year. This production required dancing

${ }^{16}$ Cohen, Pg. 121. 
throughout the entire run. Part of the auditioning process for Black Nativity was to perform part of Mrs. Tina's choreography that she was preparing for the show. Not only did I get cast, but I also got the lead role because I was a surprisingly good dancer. From then on, Mrs. Tina always cast me as a dancer in her productions. She encourag ed me to take all of her dancing classes, which led her to turn me into a dancer. Even though dancing was not my first passion, I have always enjoyed it. For me, dancing enhanced my ability to express freely without worrying about my weaknesses, particular ly my voice. I started to develop my own approach by tapping into what my body was telling me to do. A simple word for this would be "impulse." Author Patricia Relphs begins her own chapter in the compilation text Movement for the Actor, a compilation text of different movement approaches for acting, where she talks about how important it is for actors to be in tune with their intuition. In her chapter "The Bodily Expression of Emotional Experience", she opens with the following statement:

Performing arti sts have a special need to understand the body's fundamental expressiveness, from full body movement to subtle, visceral activity. Today when a performer prepares a role for stage or camera he is likely to rely exclusively on intuition or limited personal experience. ${ }^{17}$

As a young actor at the time, I did not know how to express myself comfortably without any inhibition until I explored dancing where I had the freedom to explore my physical capabilities. Freedom is an important word for a young actor, because acting is not just possessing a character's words but it is about embodying the character as well. The actor must be

\footnotetext{
${ }^{17}$ Relph, Patricia. Movement for the Actor Ed. Rubin, Lucille S. 1st ed. New York, New York Drama Book Specialists 1980. Print. (pg.29).
} 
"free to think, feel, touch, and be touched. Above all, the actor's imagination must be

unhindered." ${ }^{18}$ Furthermore, playwrights provide the actors with the circumstances of the characters, but the actor determines how to use their ability and their imagination to bring texture to what the playwright is doing. Stella Adler, a renowned acting teacher and founder of the Stella Adler Studio of Acting is known for teaching actors to use their imaginations to arrive to the circumstances of the character. In Alison Hodge's edited anthology, Actor Training, David Krasner uses, his section "Strasberg, Adler, and Meisner" to elaborate on Adler's approach to imagination. He uses a quote from Adler originally cited in Lee Strasberg's Acting and the Training of the Actor:

Thro ugh the proper use of craft, the actor will see the differences of social, historical and cultural environment between himself and the character. Through his craft he will be able to translate these difficulties and use them to arrive at the character. ${ }^{19}$

This makes sense, because when I was in the early stages of rehearsals for shows, I had to depend on my imagination because there was no set, props, or costu mes that I could refer to. However, when the time came to when I was actually onstage with everything I needed, I was prepared because I was able to use my imagination when nothing was available.

Russian theatre practitioner and pioneer of modern theatre, Konstantin Stanislavsky, influenced other theatre practitioners including Adler to use his methods as a platform for developiong their own methods. Sharon Marie Carnicke, another author from the Actor Training,

\footnotetext{
${ }^{18}$ Cohen, Pg. 13.

${ }^{19}$ Hodge, Alison. Actor Training Second ed. New York, New York USA Routledge 2010. Print. (pg. 153)
} 
expounds on Stanislavsky's systematic approach to imagination in her chapter 'Stanislavsky's System". She cites from Sobranie Sochinenii's An Actor's Work on Himself, Part I:

The system values an actor's capacity to treat fictional circumstances as if real, to visualize the details of a character's world specifically and to daydream or fantasise about the events of the play. Stanislavsky taught that an actor should not speak without an image in the mind's eye and suggests developing a filmstrip of images to accompany the performance of ever role. Such visualisation energises the imagination. ${ }^{20}$

This made me think about when I performed in Fences and I thought about the details of what the set was going to be like. I knew that there was going to be a house onstage and a dirt front yard. So when I was in rehearsal I would think about certain details of what my character, Troy, and what his world would look like. What was my porch going to look like? What would the dirt feel like under my feet? I knew that I was going to have a post on the front porch of the house. I started to implement how I would lean on the post, or if Troy would even lean on the post. I thought about the sensation of my character; who was a former baseball player, picking up a baseball from the yard. All of these images were developed, before we started the run of the show.

After four years of undergrad, I was one of the core actors in the program and eventually I was a mentor to many of the acting students. Overall, what I got out of the program, besides the obvious education, were lessons beyond a book and pertained to life in general. I learned that in order to succeed in anything, I have to make sacrifices for myself. The second lesson was to make sure that the work that I do as an actor inspires others. There were times that I would have no gas

${ }^{20}$ Hodge, Pg. 11 
in my car, or I would be riding in the snow with sleek tires on my way to do a show.

Nevertheless, it did not matter to me because there was some nights I would be signing autographs after a show. Imagine me an amateur actor signing autographs. But it was mostly children who were asking for my autographs. This revealed to me that this work had a higher purpose than the popularity aspects of it. I felt the purpose to inspire others. Another lesson that I learned is that it is not always about what you know, but about whom you know and the relationships that you establish within your field. That lesson was invaluable to my career and to my future as a working actor. Throughout my time during undergrad and eventually during graduate school, I learned that it is best to focus on the process and not so much on the product. Understanding that now allows me to look back at those early days as an actor in NC A\&T and realize that those years were a significant part of the process of becoming the working actor that I wanted to be. 


\section{What did I do to confront the weaknesses?: The Labor of Graduate School}

Over the course of my time in graduate school at The University of Louisville (UofL), I developed techniques to improve my diction. I still needed to work on my voice a lot more than I thought, but I was happy to find some clarity on what I was doing wrong. Because of my history of putting too much emphasi s on my consonants, I discovered that was the source of my vocal issues. Not only was I able to identify what the issue was, but I was also developing a vocabulary in voice work that I now can use to communicate to others and myself on what I needed to work on as an actor. Good speech is creating sounds with proper articulation. Articulation is the "shaping of vocal noise into independent and recognizable units of spoken language." ${ }^{21}$ My voice professor, Ashley Smith, reintroduced me to the International Phonetics Alphabet (IPA). This was helpful in my journey towards developing my articulation. IPA is an alphabetical chart for speech sounds, and it is valuable for an actor because not only can one improve their diction, but they can also learn how to do various dialects and accents using this alphabet. Another thing that helped me was learning the different categories of speech sounds. Without looking in-depth on the mechanics of making those sounds with our mouths, we do not know how to recognize any problems. For example, for native English speakers, our vowel sounds are broken up in three areas of our mouths: the front of the mouth, in the back, and in the middle. We call these front vowels, back vowels, and mid vowels. ${ }^{22}$ Cohen talks about vowels in his chapter entitled, "Stage Speech", and why it is important for actors to speak the vowels clearly in our lines:

Learning to speak vowels clearly and cleanly, and to hear the difference between vowels in similar-sounding words, is particularly important to the actor because the vowel

${ }^{21}$ Cohen, Pg. 121.

${ }^{22}$ Cohen, pg. 122-123. 
sounds of stage speech carry the tone of the dialogue and convey the nuances of a character's tactical pursui ts. ${ }^{23}$

Learning the different categories of consonants in speech was beneficial as well. "Vowels are produced speech sounds through an open configuration of the mouth with no hindrance," ${ }^{24}$ where as a consonant breaks the speech sounds by partly obstructing the breath that makes the sounds. ${ }^{25}$ The obstruction of the sounds comes from how we use our mouths to make the sound using our tongues, lips, teeth, nose, and the hard or soft palates, which are located at the roof of our mouths. Here are examples of the differences between vowels and consonants:

Vowels:

Front Vowels:

$e e$ as in beet, heat, feel, see seize

Back Vowels:

ah as in father, Charles, hard, party

Mid Vowels:

$u h$ (stressed) as in cup, rubble, ton, up, none $e^{26}$

\section{Consonants:}

Plosive Consonants:

${ }^{23}$ Ibid.

${ }^{24}$ New Oxford American Dictionary: Oxford University Press, Inc, 2010, 2016. Print. See Vowel

${ }^{25}$ New Oxford American Dictionary: Oxford University Press, Inc, 2010, 2016. Print. See Consonant

${ }^{26}$ Ibid. 
$t$ as in tickle, touch, ten

Fricative Consonants: $f$ as in football, fill, from

Nasal Consonants: $\quad m$ as in mystery, men, meal

Glide Consonants: $\quad l$ as in leader, listen, look

\section{Blended Consonants:}

ch as in chipmunks, choke, child ${ }^{27}$

On paper, vowels and consonants work hand-in-hand. I realized that this was tedious work, but it was also very crucial in my efforts to improve my articulation. What aided me with my speech was that I looked at the words like the complete structure of a bridge. The consonants are the support beams for the word, while the vowels are what carry you across the bridge. When I was in undergrad I was paying too much attention on the support beams and not enough on what was supposed to carry me across the bridge. Now I had a better understanding on how to enunciate my words better. This was the beginning of my journey of enhancing my craft as a working actor.

My movement classes were beneficial as well, because I was using my strongest asset, my body. My first movement professor at UofL, Professor Erin Crites, expanded my body's capabilities. I lacked technique and Erin introduced us to a multitude of techniques, including

${ }^{27}$ Cohen, pg. $124-125$ 
Laban. Laban is a theoretical structure that observes qualitative and quantitative changes in movement, from regular hand gestures to complex actions. ${ }^{28}$ The technique is named after its founder, Rudolph Laban, who was a theorist on movement for the actor. The significance of this style of movement is that it enhanced my impulses to move on stage. Laban created principles to support his qualitative and quantitative explorations: Body, Effort, Shape, and Space (BESS). ${ }^{29}$ Each principle is a container that holds certain elements within our bodies; the exploration aspect relies on how all the principles affect each other. This type of work and more helped me explore how my characters' behavior informs my body and what each character is supposed to look like. For the first time, I was able to figure out how to take the internal facts of my character and turn it into a physical manifestation.

Lastly, the art of language was probably the biggest lesson that I learned in the program. The unique thing about this lesson was that I did not learn it in the classroom, but it was when I was actually doing the work, acting or as Cohen states: "Diction is not something you learn from a book. You learn it from experience, both on stage and in life." ${ }^{30}$ Dr. Baron Kelly was my toughest professor and director, but he was also one of my biggest influences in the department as a mentor. The first show Professor Kelly directed me in was the play, The Meeting, written by Jeff Stetson. It was a fictional story of Martin Luther King. Jr. and Malcolm X's only meeting in a hotel room during the 1960's. I played Dr. King, and we were performing the show for the annual Martin Luther King, Jr. celebration at UofL. During rehearsal, every time I spoke a line from the script, Baron stopped me and would have me repeat the line for two reasons: 1.) I was

\footnotetext{
${ }^{28}$ Adrian, Barbara. Movement for Actors New York, New York Allworth Press, 2002. Print. (pg.73)

${ }^{29}$ Adrian, pg. 74

${ }^{30}$ Cohen, pg. 180
} 
not saying the line right according to the meaning and punctuation; 2.) I paraphrased or incorrectly said the line. What was even more demoralizing to me was that he did not even have the script in his ha nd but he knew when I was wrong. He told me that I was not "sensitive" to the language, and I could not understand what he meant at first. Eventually, I learned that Baron was trying to get me to understand that I was not using the proper phrasing. Phrasing is technically constructed through diction, emphasis, and inflection. ${ }^{31}$ Overall what phrasing does is give the actor the mechanics for the meaning behind the words. To me, diction has always meant speaking clearly. What I did not know is that it also meant speaking clearly with meaning. Robert Cohen says that diction "is the clarity with which words are enunciated and put into action." 32 One of the biggest rules in theatre is to play action not emotion. What that means is that when you are acting, your character must be doing something actively with their words to provoke the other characters. The emphasis on specific words is the oral interpretation, which must be aligned with the syntax or the arrangement of the text. You can alter the meaning of a line by simply changing the emphasis on a word based on how it is written on the page. Here is an example of a line from Fences. Troy is as king his son Cory if he is working at the A\&P grocery store:

TROY Ain't you suppose to be working down there after school? $?^{33}$ Placing the emphasis on "there" makes the location that Troy is talking about explicit in the phrase. In rehearsals, Baron would refer to this as "calibrating text." Another way of doing this is by using subtext. Subtext "is the hidden meanings of a dramatic text, comprising its inner

\footnotetext{
${ }^{31}$ Cohen, Pg. $177 .$.

${ }^{32}$ Ibid.

${ }^{33}$ Fences Pg. 37.
} 
actions and the unstated goals of the characters." ${ }^{34}$ The subtext should be aligned with the action. For example, if I am trying "to convince" Cory that he should work at the grocery store the subtext might inform my emphasis on the word you. It all depends on the character's objective in the moment. Inflection deals with pitch and is similar to emphasis, but the difference is that it deals with the entire sentence plus it is a specific way of emphasizing one or more words. For instance, traditionally when we ask a question there is a rise or fall in our pitch towards the end of the question. The feeling about the subject that we are asking a question about determines how we use the inflection. If we were asking a question about something that excites us, the sentence would have a rising inflection. But if that something does not excite us or if we are trying to avoid something, the inflections are down. If we are pointing out the antithesis or opposites we put emphasis on the two subjects that are being compared. For example:

I like the color red, but not blue.

I would give red a higher inflection than I would blue. This part of language is something we do everyday, but when it is on paper we forget that it is a part of what we do all the time. In undergrad, I had a band director that used to tell us when we were learning new songs: “Don't be afraid of the black on the paper." He was trying to tell us not be afraid to play what is in front us, especially if we knew how to play. In the four productions that Baron directed me in he has helped me become more sensitive to the language. In the first show, The Meeting, he made me more aware of the language within the text by casting me as Dr. Martin Luther King and challengine me to understand his use of language. In The African Company Presents: Richard III, he challenged me even more by casting me in a role where I had to learn a different dialect.

\footnotetext{
${ }^{34}$ Cohen, Pg. 519
} 
Lastly in The Piano Lesson, the first Wilson play that he directed me in, he helped me become aware of the specific language of Wilson prior to Fences.

The process of learning techniques such as Laban and identifying vocal problems were helpful in providing me with the necessary tools to perform. What I was not prepared for was playing my toughest role as Troy Maxson from Fences. Even after the advanced training at UofL, I lost my initiative for the work in the beginning of my process. I was going into my third year in graduate school, and I was feeling apprehensive about the work that was ahead of me. I was getting tired mentally and physically. Even though the work that I was learning was beneficial, the constant critique in my work was daunting, specifically from Baron. In the program it was mandatory that we have reviews throughout the semester. These reviews encompass not only our work in the classroom, but also our performances on stage. Like I previously stated, my most critical person of these reviews has always been Baron. In this type of work, you are never perfect and it is something that we as actors have to accept. My rehearsal process in Fences was challenging, but through the work and lessons that I learned through the play, I was able to get a valuable lesson from my character. Nevertheless, I wondered how does a person stay positive about the work that they have done in spite of critiques, especially when you are working with "the critic." 


\title{
SECTION THREE
}

\author{
Oh... To Be Troy Maxson: The Labor of Creating Troy Maxson \\ "Oh... to be Hamlet! Ahh... to be Juliet! To be St. Joan, or Eliza Doolittle, or 'Enry 'Iggins for \\ the few hours allotted by the playwright! If you really want to be, you'd better know who you are \\ when the play begins, and how you got to be that way!'- Uta Hagen ${ }^{35}$
}

\section{My Journey through the process}

I have been acting for approximately eight years, and I have to admit that every role I have been involved in has always been a different creative experience for me. There has never been a time where I had a rehearsal process that was similar to a previous one. However, I can say that each character I have played I have created a special bond with them. They might be by definition, fictional characters, but the circumstances of most characters are underlined with some sense of truth, whether it is hidden by metaphors or related to factors of everyday life. This relationship between the character and the actor is unique because usually there is only one human that is used, and that is the actor because he or she is the real person amongst this companionship. Although the character-actor connection makes practical sense, it does not mean it is a simple task for the actor. This type of human connection takes practice, but more importantly, it takes work.

The type of work it took me to build the character, Troy Maxson, was unique for several reasons, but mostly because of the journey. This particular journey started way before I even

${ }^{35}$ Hagen, U., Respect For Acting 1973, 2008, New York John Wiley \& Sons, Inc (Pg.152) 
picked up the script. It started when I began to lose that initiative that I felt like I possessed earlier in my life. During the latter of spring 2016, I was cast as Troy Maxson's brother Gabriel, or Gabe, for my thesis role in the upcoming fall se mester. Gabe is Troy's younger brother who has suffered brain damage for fighting in World War II. However, Baron the director, was under the assumption that I had the desire to play Troy because it was the lead role. I had already denied my thoughts of even playing Troy because of the vast age difference. At the time, I was 29 and Troy is 53. A 24-year difference is a very significant time span when it comes to the human experience, especially when I would be trying to emulate a black man who lived in the middle of $20^{\text {th }}$ century America. Although I understood why I could not play Troy, I was offered to play him because of scheduling conflicts with the original actor cast for the role. The role was offered, and I simply accepted it in spite of my initial reas ons for why I could not do it, which clearly proved the director's assumptions.

Although the sudden change in casting happened later during the summer, it did not negate me from being unprepared during the premature stages of my process. I was unprepared because I was procrastinating with learning my lines and doing my research on the character, which are just basic duties of the work of an actor. Since then, I have been curious about my reasons for being lazy, being that this was my thesis role and one would think that I would do everything to make this a great performance.

I read a journal article from Surface Fabrication titled "Procrastination." The purpose of the article was to inform business managers with an understanding of procrastination and how to combat procrastination from employers. This information was significant to me, because it 
defined the potential reasons for my procrastination. The journalist, Jon Olson, had some interesting insights, about the attitude that people have towards their work.

I think for many, procrastination is a symptom of another problem, a less than ideal attitude toward the work they are doing. Consider the following statements:

I don't have the desire or the drive to do the assignment.

I just get to things when I feel up to doing them.

I want to do something else.

Chances are that if you were to analyze your workers with a tendency to procrastinate you would find those employees in agreement with at least one of the above statements.

Often when we first hire employees, they produce very well, but as time goes on there is a decline in performance. ${ }^{36}$

Reading this article led me to ask myself the following questions: Did I not have the desire to do my work as an actor? Moreover, did I not want to act anymore? After answering these questions to myself, I realized that the desire to do theatre was not gone, and I did want to continue this work. The problem was that the institution of academia had been daunting for me, and it did not help that the director who I was working with had been my most vocal critic since I had been in the M.F.A. acting program. In the previous chapter, I mentioned how critical Baron was about my work in my semester reviews. Coincidentally, the last review that I received from him was actually good. What made this a coincidence was that the show that I was doing around

\footnotetext{
${ }^{36}$ Olson, J., Procrastination. Surface Fabrication. Feb, 2008. 14(2): p. 20.
} 
that time of the review was The Piano Lesson, which was also directed by Baron. When I played the character Boy Willie in The Piano Lesson during the fall semester of 2015, I was very apprehensive about the wo rk that I did. I did not think it was a success for multiple reasons: 1.) I blew my voice out before opening night because I was yelling so much. 2.) It was the most physical demanding role that I have ever played. 3.) A lot of people saw the production, including one of Louisville's known critics Keith Waits:

This is certainly a role designed to dominate, and I have no doubt that Samuel L. Jackson and Charles S. Dutton were anything but shrinking violets in the role, but while Mr. Madden's ferocious attack on the character is impressive for its energy and commitment, hitting the stage full steam leaves the character with nowhere to develop, and the loudmouth Boy Willie became grating. ${ }^{37}$

So not only was I critiqued harshly, but I was compared as an underling to the famous predecessors who played Boy Willie. It was difficult to get excited about the work after that performance, especially when several people have been questioning your work. That was a year before I did Fences, unfortunately I let my experiences with the director, and my previous performances, dictate my approach to the rehearsal process. Therefore, instead of proving everyone that I was good enough to do the work, I procrastinated. Instead of avoiding my duties, I should have done what I was supposed to do, because at the end of the day it had to be done. ${ }^{38} \mathrm{I}$ have had issues throughout my graduate career with maintaining my passion for the work because

${ }^{37}$ Waits, Keith. "Not the Lesson You Imagine." Arts-Louisville (2015). Web. 2015-1119. ---. "One Man’s Salvation." (2016). Print.

${ }^{38}$ Olson, Pg. 20. 
of harsh critiques and not feeling like I had done any satisfactory work during my time here. Having someone analyze your work is necessary, and I would not advise anyone to run away from that critical voice. However, after being at UofL for two years, I wondered if any of the work I had done was exceptional.

Procrastination was not the only impediment in this process. The mental and physical differences between the character and myself were so vast. As I mentioned earlier in this chapter, the age and the social construction of Troy Maxson added some pressure during the beginning of my process because of our different circumstances in life. Here is a list of many significant differences that I had to consider between Troy and me:

- Relationships:

○ Tyler-3-Year Relationship

○ Troy- 18-Year Marriage

- Children:

○ Tyler- A Dog named Blue

- Troy- 3 children ( 2 older sons, 1 daughter later in the play)

- Age:

○ Tyler- 29

○ Troy- 53 
- Occupation:

○ Tyler- Actor

○ Troy- Sanitation Worker

- Birth Year:

○ Tyler- 1987

○ Troy- 1904

- Education:

- Tyler- College Degree and two years of graduate school

○ Troy- Did not attend school and cannot read.

- Relationship with parents:

- Tyler- Both parents are alive and present in my life.

- Troy- Mother left when he was 8 years old, and he left his father's house after an altercation at the age of 14 years old; he has not seen them since.

- Issues with the law:

- Tyler- A couple of traffic citations

$\circ$ Troy- 15 years in the penitentiary for robbery and murder 
The significance of this information is that these categories construct both our social and psychological views on life. This makes my job as the actor more complicated than it would be if I were playing an actor closer to my age or life experiences. If this was a professional show, I would have not been considered for this role at my age, but I did not let that become too much of a nuisance for me. Moreover, I remembered that as long as I had my sense of imagination that I was still capable of doing this work. Throughout this process of creating Troy, I used the given circumstance of certain scenes to inform my imagination. In fact, in the beginning of Act 1, Scene 2, when Troy wakes up the next morning after a night of drinking and having sex with Rose, I thought of operative words that were symbolic of what Troy might be experiencing, like stiffness, or not being fully awake. Once I got into the space, I started to use the lights as an indication of the sun being in my eyes to suggest that I was just waking up. If I could not use my imagination, I used models and examples to create the physicality of Troy. When I would do something as simple as stand, I would use my grandfather's tendency to be open in the chest as a platform for stature. Despite the mental and physical differences between the character and myself, I found similarities between Troy and I that helped me connect. One of them was that Troy and I have both worked blue collar jobs or jobs that were less desirable. Another example is how we own up to our mistakes. I mentioned how it was my fault for not being fully prepared for my thesis role. In the play, Troy admits it is his fault for his infidelity:

TROY It ain't about nobody being a better woman or nothing. Rose, you ain't the blame. A man couldn't ask for no woman to be a better wife than you've been. I'm responsible for it. I done locked myself into a pattern trying to take care of you all that I forgot about myself. $^{39}$

\footnotetext{
${ }^{39}$ Fences, Pg. 66.
} 
The most direct similarity that Troy and I had was with our pets. Troy mentions that when he was a kid he had a dog and his name was "Blue." Coincidentally, I currently have a dog named Blue.

This role was appropriate for graduate student level acting, because the purpose of graduate training is to prepare you for a profession by accepting rigorous tasks. A practical analogy for this is lifting weights. You do not gain strength by lifting what is comfortable to you, but you lift what is uncomfortable to get stronger then you were before. Once I realized this I did not let my differences become a hindrance in my process. Instead of prolonging the procrastination, I started my process by breaking my character down from the script. 


\section{What does the text say about Troy?}

There is no better source than the script. It is the wellspring of an actor's process, because it is where you start as far as understanding the play and the character. The script of August Wilson's Fences is where my process started. Fences is one of August Wilson's most critically acclaimed works, awarded with multiple awards including a Tony and a Pulitzer Prize. From the language that his characters speak to the vivid description of his characters in the stage directions and parentheticals, August Wilson illustrates his work primarily through language. To understand who Troy Maxson is, you must begin with Wilson's initial description of the character, which is presented in the opening scene. The first scene in the play opens up with Troy and his longtime friend, Bono, whom he met while he was incarcerated. They are coming home from work. Before the scene opens up with dialogue between the two friends, Wilson gives a brief but significant description of Troy's physical stature and demeanor through descriptive imagery:

TROY is fifty-three years old, a large man with thick, heavy hands; it is the largeness that he strives to fill out and make an accommodation with. Together with his blackness, his largeness informs his sensibilities and the choices he has made in his life. ${ }^{40}$

Although this is a brief description, it gives me as the actor ideas of who Troy is by looking at key words that the playwright provides. Words or phrases such as "thick, heavy hands", "largeness", and "blackness" are words that describe Troy's physical presence and what his demeanor might be before you actually read the dialogue. Uta Hagen suggests in the chapter

\footnotetext{
${ }^{40}$ Fences, Pg. 7
} 
titled, "First Contact with the Play", that after you read the play once, you should read it again and again. ${ }^{41}$ So it is fair to say it was required of me to read this play several times but specifically from Hagen's perspective, to not make my initial assumptions of who Troy is, and to not confuse my organic identification that I must find with the character. Although I was already familiar with the play before the decision was made for the Theatre Arts Department to produce Fences, I already knew that the play was centered on African American life in 1957 Pittsburgh, Pennsylvania. Since I was a black man, the words used to describe who Troy is connected to my experiences. Based on the words, I assumed Troy was a man who looked for attention particularly when people were around. His personality would be fitting to his stature of largeness, while simultaneously considering his "blackness" as something that he cannot and will not resist. When August Wilson mentions Troy's blackness, he is referring to the quality or fact of being of black African descent. $^{42}$

The majority of the clues that Wilson gives for us are embedded in the actual lines; it is the characters' job to inform us on who each person is by giving us information within the dialogue. Fortunately, for me playing Troy, I was able to get a vast understanding of the character within the first scene without exposing too much of the story. From the first scene of the play, certain information about Troy are established within the dialogue:

He is married and faithful to his wife:

TROY Look here, as long as you known me ... you ever known me to chase after women?

${ }^{41}$ Hagen, Pg. 148.

${ }^{42}$ New Oxford American Dictionary: Oxford University Press, Inc, 2010, 2016. Print. under Negritude 
BONO Hell yeah! Long as I done known you. You forgetting I knew you when.

TROY Naw, I'm talking about since I been married to Rose?

BONO Oh, not since you been married to Rose. Now, that's the truth, there. I can say that. $^{43}$

He is a former baseball player:

TROY It ain't gonna get him nowhere. Bono'll tell you that.

BONO If he be like you in the sports ... he's gonna be alright. Ain't but two men ever played baseball as good as you. That's Babe Ruth and Josh Gibson. Them's the only two men ever hit more home runs than you.

TROY What it ever get me? Ain't got a pot to piss in or a window to throw it out of.

ROSE Times have changed since you was playing baseball, Troy. That was before the war. Times have changed a lot since then. ${ }^{44}$

He has two sons:

TROY (Hands him the bottle.) The only thing I say about the A\&P is I'm glad Cory got that job down there. Help him take care of his school clothes and things. Gabe done moved out and things getting tight around here. He got that job.... He can start to look out for himself.

ROSE Cory done went and got recruited by a college football team. ${ }^{45}$

Later on in the scene Lyons, Troy's oldest son enters the scene:

LYONS Hey, Pop.

TROY What you come "Hey, Popping" me for? ${ }^{46}$

This is deductive information that tells us a lot about what the characters have going on in their lives, which gives the actor information to play with during rehearsals. That same process of

\footnotetext{
${ }^{43}$ Fences, Pg.10.

${ }^{44}$ Fences, Pg.14.

${ }^{45}$ Fences, Pg.14.

${ }^{46}$ Fences, Pg.18.
} 
gathering information through the dialogue is constant in a rehearsal process. There is always more information that we should be able take that informs us about our characters and gives them details. Dialogue is so unique because it depends on explicit and poetic language oratorically described.

Without getting too much into the social construction of the character, you can grasp who this character is by looking at his relationship with the people around him. For example, Troy values his relationship with his best friend Bono. This is evident by looking into their Friday night ritual of walking to Troy's house to celebrate making it through the week by sipping a pint bottle of gin. Those moments during the play are when you get to see Troy in his most jovial and comical state. He loves the convention of storytelling, which is a popular convention amongst African Americans. August Wilson and his plays are documented examples of that convention and the telling of African American stories was a part Wilson's motif. When it came to writing about black life, he closely listened to their language, speech patterns, and vernacular and studied their personalities. ${ }^{47}$ Eventually, he used that same language to tell stories of the street and to create a larger narrative landscape. ${ }^{48}$ Troy Maxson is one of Wilson's iconic characters that reflect that quality. When you see this side of Troy you get to see that he is bigger than life as Wilson expresses in his description of Mr. Maxson. This same attitude or spirit is just as valuable towards the actor that plays Troy's wife Rose, even though he eventually struggles with infidelity. Troy's relationship with his sons is the least pleasurable for him. With Lyons, he treats him as an adult rather then an adolescent like Cory, while simultaneously discrediting Lyons for being a musician and not having a stable job:

\footnotetext{
${ }^{47}$ Bogumil, Pg. $2 .$.

${ }^{48}$ Ibid.
} 
LYONS I ain't asked you to give me nothing. I asked you to loan me ten dollars. I know you got ten dollars.

TROY Yeah, I got it. You know why I got it? Cause I don't throw my money away out there in the streets. You living the fast life ... wanna be a musician ... running around in them clubs and things ... then, you learn to take care of yourself. You ain't gonna find me going and asking nobody for nothing. I done spent too many years without. ${ }^{49}$

In this piece of dialogue, you can see that even though Troy is lecturing his son Lyons, he is only suggesting what he should do with his life, because Lyons is an adult. Ironically, he is having this conversation during his Friday night ritual, while sharing his bottle of gin with his older son and Bono. This is proof that even though he ridicules Lyons he tolerates his presence. Unfortunately, Cory does not get the same treatment as Lyons. Instead of advising what Cory should do, he is literally telling him what he is going to do. Troy explains it simply to Cory, 'I'm the boss you understand? I'm the boss around here. I do the only saying what counts." the result of what happens when you are living in his house, among his rules. Troy's sternness is infectious to his family or as Rose describes him metaphorically, "I planted myself inside you and waited to bloom. And it didn't take me no eighteen years to find out the soil was hard and rocky and it wasn't never gonna bloom." ${ }^{51}$ One of Troy's more empathetic moments is within his interactions between him and his brother Gabe. Gabe is a mentally impaired veteran of World War II, who is under the care of Troy, his custodial guardian. ${ }^{52}$ Troy is more receptive of Gabe's

\footnotetext{
${ }^{49}$ Fences, Pg. 22.

${ }^{50}$ Fences, Pg.38.

${ }^{51}$ Fences, Pg.67-68

${ }^{52}$ Bogumil, Pg. 41
} 
presence when he is around mostly because he feels indebted to his brother because of his condition and because of the money that the government provides Troy for taking care of Gabe.

As I stated earlier, there is no better source than the script itself. This process of going through the script is what actors call text analysis. Text analysis is part of the process where the actor must read, evaluate, analyze, and research everything that helps illuminate your character and their world from the perspective based on the script. ${ }^{53}$ One of the significant things that I learned more from graduate school was how to scout for information by figuring out what a piece of text is doing by simply reading the play again and again, as Hagen instructs. If you read a play without being objective, you can learn a lot before adding the social parameters that surround the character. This is a significant step in my laboring process for building the character and performing Troy Maxson.

${ }^{53}$ Kenneth L. Stilson, Larry D. Clark, Charles McGaw Acting Is Believing 12th ed. Stamford, CT Cengage Learning 2015, 2012, 2009. Print. (pg. 163) 


\section{Research of the Times: 1950's America}

Troy's elements of life are rooted in his duties as a laborer and provider for his immediate family, which gives him self-gratification. Because he recognizes this, he takes it upon himself to remind everyone, while ignoring what others may give to him. I emphasize the words "take" and "give," because the respect for what each other gives and takes towards the family is an important part of Troy and Rose's conflict. Troy believes that because he is the only financial provider for his family he is the only person that is giving to his family. His position as the "provider" is not exclusive to Cory and Rose, who actually live in the house, but also to his older son Lyons who is a struggling musician and ask for money, and his younger brother Gabe, who is mentally disabled because of a war injury. Because of these obligations, Troy feels trapped, as if he has settled for an undesirable life. Even though Troy understands how important it is for a man to provide for himself and his family, he is still coping with his own desires of being a professional baseball player and having that taken away from him.

Identifying the socioeconomic world of a character is also an immense step within character development, because the world of the character is what shapes the values of that character. There is a lot of consideration when it comes to the world of a character, because you are looking at a specific time and in a specific location. Furthermore, when you have to research a retrospective reality, it becomes more tedious. You have to cross-examine the many spectrums of a character's life: how old is he? When was he born? Where does he live? What does he do for a living? What is his race? What is his gender? What year or decade is the character currently living? Ultimately, what do the character's race, gender, age, and occupation indicate within the constraints of the socioeconomic world that they currently or formerly live in? 
Troy Maxson is a black man living in America, which is a statement that conjures many discussions. However, to understand a man like Troy Maxson we must research the years that Troy Maxson supposedly lived, from the birth to adolescent years and leading up to his current age. This helps to understand who he was before the current era of the play, which is the year 1957. Troy is 53 years old, according to the script, which chronologically puts his birth in 1904 . The time of his birth was during a significant moment for African Americans but a difficult moment. His birth is approximately six years shy of the beginning of the great migration, which is the mass movement of black southerners to the urban, industrial North. ${ }^{54}$ This corresponds with Wilson having his play's set in Pittsburgh, Pennsylvania, which is one of those northern industrial cities where blacks migrated. However, before we go into the current era of the play we must recognize the journey from the sharecropper lifestyle that Troy came from. In one of Troy's monologues in Act 1, Scene 4, Troy reveals his childhood with his father, who was a sharecropper from the south. According to Troy, all his father "wanted was for you to learn how to walk so he could start you to working.. ${ }^{, 55}$ Wilson does not state precisely when Troy started working as a kid, but we can assume from the script that it was before or during his teenage years. In Steven A. Reich's, A Working People, he provides a historical account of African American laborers, including the age limit of black workers. According to Reich, the minimal age was 10 years old ${ }^{56}$ From this, we can begin to explore the premise of Troy Maxson's life and that is his journey as a laborer. To be a workingman was idealistic in early $20^{\text {th }}$-century America. But more importantly, for a black man, being able to parallel one's self with his white American male

\footnotetext{
$1^{54}$ Reich, Steven A. A Working People. Lanham, Maryland Rowman \& Littlefield 2013 Print. (pg.61)

${ }^{55}$ Fences, Pg.49.

${ }^{56}$ Reich, Pg. 41 "See Table 2.1."
} 
counterpart as a provider was important. Troy's inspiration stems from his father's example of being a provider for his family in spite of his father being unloving and quick tempered ${ }^{57}$ Instead of persecuting his father, Troy still honors his father for working and taking care of his family, which also allows Troy to justify his father's transgressions. For example, when Troy is talking to Bono and Lyons during their Friday night ritual of drinking and conjugating in the backyard of his house, he talks about and justifies his father's abusive actions:

No, he was trapped and I think he knew that. But I'll say this for him... he felt a responsibility toward us. Maybe he ain't treated us the way I felt he should have... but without that responsibility he could have walked off and left us... made his own way. ${ }^{58}$

Even though he is not a complete replica of his father growing up, Troy works from the memory of how his father worked and provided for his family, despite his own faults in his life such as developing a reputation for robbing and stealing money. Troy went to prison for 15 years for his crimes, but once he got out of prison he did not return to his thieving habits:

But that fifteen years cured me of that robbing stuff. Rose'll tell you. She asked me when I met her if I had gotten all that foolishness out of my system. And I told her, "Baby, it's you and baseball all what count with me." ${ }^{59}$

Troy is proud of how he succeeded after his time in prison, and he tries to teach Lyons and Cory to not make the same mistakes that he did: "I done learned my mistake and learned to

\footnotetext{
${ }^{57}$ Bogumil, pg.40.

${ }^{58}$ Fences, pg.50.

${ }^{59}$ Fences, Pg. 53-54.
} 
do what's right by it." ${ }^{60}$ However, the same unloving attitude that his father had towards him is the same attitude that he has towards Cory. He emphasizes to Cory that he is the provider for his family, just like his father was and Cory is suppose to respect his father's position despite his faults.

Coincidentally, Troy was also a dreamer like Cory. While Cory is fortunate to have an opportunity to play football in college, Troy at one time was living the dream of doing what he loves to do, which was playing baseball in the Negro Leagues. Unfortunately, that dream is no longer a reality in the play. By the time minority baseball players such as Jackie Robinson and Pittsburgh Pirates' icon Roberto Clemente played, Troy was too old to play Major League Baseball. This was something Troy resented. He expressed his frustration particularly when speaking about Jackie Robinson:

I done seen a hundred niggers play baseball better than Jackie Robinson. Hell, I know some teams Jackie Robinson couldn't even make! What you talking about Jackie Robinson. Jackie Robinson wasn't nobody. ${ }^{61}$

Jackie Robinson was not only the first African American baseball player in League history, but he won the rookie of the year award in 1947 and was honored with the Most Valuable Player award in $1949 .{ }^{62}$ For Troy to make such a bold statement was an outrageous thing to say during the time of the play.

${ }^{60}$ Fences, Pg. 22.

${ }^{61}$ Fences, Pg.15.

${ }^{62}$ Robinson, Rachel. "Jackie Robinson." Essence (Essence) 27.7 (1996): 52. Print. 
Instead of being able to live out his dream and true passion for baseball, Troy had to settle with being a sanitation worker for the city of Pittsburgh. The positive aspect of Troy being a sanitation worker from a social perspective is not based on the job description, but is simply based on the fact that Troy is a black man with a job and is able to provide for his family. Fortunately for Troy in the 1950's, it was slightly easy for African Americans to get employment because of the hardships that the war had put on American laborers. This led to opportunities for blacks that were leaving the south looking for work in the northern states, particularly in inner cities such as Pittsburgh. This is one of the reasons for the birth of the Great Migration. Even though the Great Migration north started during the early to mid-1910s, it was a precursor for the state of blacks laborers in the 1950s. In David Schwartzmam's Black Unemployment, he gives specific details on American economy during the time of the play, which is set in 1957. Even though Troy has a job, the statistics in this publication gives an economic perspective for blacks during the period. It reveals that as a sanitation worker Troy has it better than some blacks in the 1950s, which proves how important it was for Troy to keep that job. This was interesting to me, because it reveals how much of a mere privilege it was for a black man to even have a job.

The concept of being a provider for his family also allows Troy to force his patriarchal position on his family. Being an employed black man and making decent money informed me of the economic privilege that Troy believed in even as a character in the 1950s. In his first chapter, Schwartzman talks about the inevitable issue of unemployment amongst blacks. The early 1950's unemployment rate for black males was only 5.4 percent, about half the current rate. ${ }^{63}$ The time period that Schwartzman was comparing this percentage to was the late 1990s. He goes further in

${ }^{63}$ Schwartzman, David. Black Unemployment: Part of Unskilled Unemployment Westport, CT USA Greenwood Press 1997. Print. (pg. 2) 
saying: "Black unemployment was higher than white unemployment, but the early 1950s was a golden age for blacks compared to today." ${ }^{, 64}$ Before and after the 1950 s, the typical choices that a man had as far as working was to move north and seek work like Troy and Bono, join the military and fight in wars like Gabe and Cory, stay in the south like Troy's father, or work as a working musician or end up in prison like Lyons. It is a coincidence that Lyons, who Troy was not around to raise, ended up in prison like his father. Despite the employment boom for blacks during the plays period, the jobs were still limited to lower positions and Lyons could not find work that he felt suited him, which resulted to criminal activity. Similarly, Troy struggled to find work during his young adult years. The United States did not enter into World War I until 1917, which was only a year before it ended in 1918. This is around the same time Troy left his father's home, but he would have been too young to enlist at this time. When he decided to move up north around 1917 , he was not fortunate enough to find any fair opportunities for work, so he became a criminal, as he states during one of he and Bono's Friday night drinking sessions:

Went out one day looking for somebody to rob ... that's what I was, a robber. I'll tell you the truth. I'm ashamed of it today. But it's the truth. ${ }^{65}$

By the time the US entered World War II in 1941, Troy has been out of prison for murder and robbery for approximately five years after a 15-year sentence. During his time in and out of prison, he was seeking his newfound passion in baseball. Once again, Troy did not find economic success in baseball because the league was segregated at that time.

\footnotetext{
${ }^{64}$ Ibid

${ }^{65}$ Fences pg.53.
} 
In spite of Troy's issues in life, the one thing that he is proud of is his position as the head of the household. Most of Troy's pride as a provider and the way treats his family stems from the patriarchal system of the family, which serves as an orthodox structure of running a family in America. The Dictionary of Critical Theory provides supportive theories of my character and the setting of the play as a whole. More specifically, the source definition on patriarchy was necessary to my research. Troy is a black man in the 1950's living in a strongly patriarchal society. Patriarchy is so much a part of Troy that it almost defines everything that he is. Although the primary meaning of patriarchy is "rule of the father," describe the systematic structure of having the father or the eldest male in a family as the head of the family. ${ }^{67}$ Patriarchy was and is a common practice in American society. It was prevalent in the 1950s, and more so in characters like Troy Maxson. However, the structure of patriarchy is not the same for Troy, because he is not just a man, he is a black man. The position of being head of a household is a contradiction for an African American who by society's definition is inferior to the dominance of white Americans. That is Troy's main conflict, which he cannot really articulate or fully come to an understanding for himself, particularly as it relates to the opportunities that he lacks to fulfill his dreams of playing Major League baseball. Conversations with August Wilson is a literature compilation of interviews throughout August Wilson's career. The interviews in this book extend chronologically from the beginning of Wilson's career until his sudden death in 2005. This text features some of Wilson's most famous interviews. In many ${ }^{66}$ New Oxford American Dictionary: Oxford University Press, Inc, 2010, 2016. Print. (pg. 291).

${ }^{67}$ New Oxford American Dictionary: Oxford University Press, Inc, 2010, 2016. Print. See Patriarchy. 
of these interviews, he talks about his writing process and social issues in most of his famous plays, including Fences. Knowing his ideas and methods gave me a sence of what he is looking for out of his characters and their overall purpose for being in the show. For my research in Fences, Wilson provides clarity to Troy's biggest conflict, which is being equal by American standards while maintaining self-pride. Having a personal connection is important, but knowing an absolute reason for the character's presence in a play was important to the process. For example, in the beginning of the play Troy talks to Bono about the discrimination that they face at his job as sanitation workers. Troy and Bono's job is to ride around on a garbage truck and pick up trash around the city, but it excludes them from actually driving the truck because they are black. Instead of Troy submitting to his circumstances, he resists by confronting his manager, Mr. Rand, about it:

I ain't worried about them firing me. They gonna fire me cause I asked a question? That's all I did. I went to Mr. Rand and asked him, "Why?" Why you got the white mens driving and the colored lifting?" Told him, "what's the matter, don't I count? You think only white fellows got sense enough to drive a truck. That ain't no paper job! Hell, anybody can drive a truck. How come you got all whites driving and the colored lifting? He told me "take it to the union." Well, hell, that's what I done! Now they wanna come up with this pack of lies. ${ }^{68}$

Here in this monologue he is pointing out Troy's attempt to be considered equal with white American men and fight for racial equality. Although assimilation has worked for some of

${ }^{68}$ Fences Pg. 9 
the black middle class, Wilson has always felt that assimilation has not been productive for African Americans. ${ }^{69}$

Since Troy is having this conflict with living within white American patriarchy, he is not recognizing the contributions that other members of his family are making, particularly his wife Rose. Rose is the matriarch of the family, who is a "stay at home" mother and wife. Troy loves Rose, but he does not respect her position in the family. He sees himself as the only person that is actually doing the giving in the family while simultaneously not realizing he is taking. This exposes the downside of Troy's "bigger than life" demeanor, where he feels like he deserves all the credit. Even when he gets caught in his infidelity that leads to the birth of his daughter, Raynell, he tries to justify his wrongs with how he has provided for his family. Ultimately, Troy could not cope with not being anything bigger than a 53-year-old garbage collector. He makes this clear during this argument with Rose after admitting his infidelities:

TROY Rose, you're not listening to me. I'm trying the best I can to explain it to you. It's not easy for me to admit that I been standing in the same place for eighteen years. ${ }^{70}$

Troy Maxson had his issues, but he is still a character that I could admire because of what he represents to me as a black man. I have performed in three August Wilson plays, but what I like about Troy's character the most is that he serves as a counter reaction of the black male stereotype. Troy subverts the bigoted view of the African American male: the lazy, shiftless,

\footnotetext{
${ }^{69}$ Conversations with August Wilson. University Press of Mississippi 2006. Print. (pg. ix)

${ }^{70}$ Fences, Pg. 67.
} 
inarticulate, and irresponsible man who abandons his family. ${ }^{71}$ This was deliberate of August Wilson to counter that false notion of the black man. An important topic of my research is talking about issues amongst black males in the American patriarchy. The core of those issues begins with the stigmas that come along with being a black man in America. In Keith Clark's Black Manhood in James Baldwin, Ernest J. Gaines, and August Wilson, he examines textual dramas that challenge and reconfigure the conditions of black masculinity. Having writer James Baldwin and August Wilson amongst the same topic is invaluable to my research, as Baldwin was influential in August Wilson's encouragement to write about black life. In addition, black masculinity is a topic that helps define my character research, while simultaneously defining myself as a black man. August Wilson's primary influences are famously called Wilson's "Four B's:" Blues, the playwright Amiri Baraka, the painter Romare Bearden, and the short story writer and poet Jorge Luis Borges. ${ }^{72}$ A blog about August Wilson argues that playwright Ed Bullins and Baldwin should be added to Wilson's list of influences. ${ }^{73}$ In most of my research, Baldwin is constantly mentioned as an influence to Wilson. Clark's book is a study on the two writers and their approach on black masculinity. Like Wilson, Baldwin does not favor blacks assimilating into white society. As Clark states:

As in most of his fiction, Baldwin foregrounds performance, voice, and community as the vehicles through which black men wrestle with and renegotiate their identities and relationships... Baldwin breaks new ground because he refuses to portray black males as long-suffering, perpetually victimized by and longing for white society. ${ }^{74}$

${ }^{71}$ Bogumil, Pg. 42.

72 Conversations with August Wilson, Pg. 223

73 "Wilson's "Four B's”." (2015). Print.

${ }^{74}$ Clark, Keith. Black Manhood in James Baldwin, Ernest J. Gaines, and August Wilson Univesity of Illinois, USA University of Illinois 2002 Print. (pg.34) 
This part of my research did not only help me connect to Troy, but it also helps me connect to a deeper understanding of what it meant to be a black man in America. It is easy to highlight some of the issues that I have encountered being a black man in America today, but it is harder to recognize what my predecessors had to go through in comparison.

In relation to my thesis, the question is how does Troy find happiness in his everyday labor-driven life? For me, it is a simple answer of just living. In all my research about Troy and what August Wilson was trying to articulate through Troy, the common thread is how Troy was "bigger than life." What this meant to me was that if you succumb to a circumstance, then you live within that circumstance. However, if you purposefully expand yourself or resist what others may say or think of you, with consideration of what might be true, then you can overcome the obstacles that exist in the circumstance. Another thing that was influential to me was Troy's way of celebrating getting through the week with his a ritualistic Friday night drinking with the men in his life. During this time he breaks into a jovial storytelling time session with his family. For example in Act 1, Scene 1, Troy brags about his battle with "death":

So don't you worry about me drinking myself to death. 'Cause I ain't worried about Death. I done seen him. I done wrestled with him. Look here, Bono ... I looked up one day Death was marching straight at me. Like Soldiers on Parade! The Army of Death was marching straight at me. The middle of July, 1941. It got real cold just like it be winter. It seem like Death himself reached out and touched me on the shoulder. He touch me just like I touch you. I got cold as ice and Death standing there grinning at me. ${ }^{75}$

${ }^{75}$ Fences, Pg. 16 
Here Troy reminisces about a tragic moment when he had pneumonia, but instead of pitying the past, he turns it into a moment of jovial storytelling. This is an example of Troy being bigger than life, because in this part of the text he is telling us that he is bigger than death, which is really the resolution of life. Mary L. Bogumil talks about Troy's "bigger than life" personality in her publication Understanding August Wilson. She states: "Rather than being completely overwhelmed by life, Troy is in many ways larger than life, a quality that garners him the respect of others." ${ }^{, 76}$ Troy talks metaphorically about death, referring to it as a physical confrontation:

I reached down and grabbed that sickle and threw it just as far as I could throw it . . . and me and him commenced to wrestling. We wrestled for three days and three nights. I can't say where I found the strength from. Every time it seemed like he was gonna get the best of me, I'd reach way down deep inside myself and find the strength to do him one better. $^{77}$

Reflecting on Troy's storytelling rituals, I learned to not allow your circumstances to suppress you. Furthermore, we should celebrate the small victories in our everyday lives. Create milestones for yourself no matter how big or small or serious they are, but more importantly celebrate the milestone.

\footnotetext{
${ }^{76}$ Bogumil, Pg. 43

${ }^{77}$ Fences, Pg. 17
} 


\title{
$6(\& 7,21 \square) 285 \square$
}$$
(1-2<, 1 * \square 7+(\square) 58,76 \square 2 \text { ) } \mathbb{2}<285 \square \$ \% 25
$$

"Turn your behind around and walk out this yard. And when you get out there in the alley .. you can forget about this house. See? Cause this is my house. You go on and be a man and get your own house. You can forget about this. 'Cause this is mine."78
\end{abstract}

\section{Where is the enjoyment?}

One of the biggest complications that I have found in acting is that the actor is never perfect. An actor is constantly criticized. Even when we think we are good, we are not. During my rehearsal process in Fences, I questioned if there was going to be any satisfaction in this work. Instead of going in the rehearsal process with optimism, I let a preconceived obstacle get in the way instead, and that obstacle was Dr. Baron Kelly.

Even though Baron and I have worked together on numerous projects at UofL, the demand of Baron as a director started to make me feel weary. This was evident in how unprepared I was during the pre-rehearsal phase in which was not learning my lines and I was not doing the research. During the process, it was mandatory that we have a journal to write in during and after our rehearsals. Coincidentally, during my first journal entry talked about losing initiative:

\footnotetext{
${ }^{78}$ Wilson, August. Fences 1986 ed. New York, New York U.S.A. : Samuel French, 1986. Print.
} 
Having initiative is the key to success in life. I had an old boss that use to tell me how much I lacked initiative. I never understood that until I finally looked it up. That was the greatest lesson that I have ever learned, and I carry that lesson with me everyday. But I have to be honest, I feel like I haven't put all my energy into grad school like I wanted to. But this year I have to just take the action of putting my foot out there. ${ }^{79}$

I did have a certain attitude towards graduate school, but at this particular moment, it was more about the work that I was doing with Baron. When I came into the program, I had just finished my undergraduate degree that took me six years to complete and made me feel that I was trained or was an expert at what I do. However, when I would work with Baron, I felt inadequate and this was a conflict for me. Even then I knew I was wrong. There was no excuse for me not being prepared for my thesis role. Nevertheless, I could not let that take an effect on the future of the production, so I moved on and concentrated on playing Troy Maxson.

One of my constant habits that Baron would always ridicule was my gesturing. I can admit that I needed to work on this. The problem was that I could not figure out how to break this habit because I was making these gestures without me knowing it. I had the correct impulse to move; it was just that the actual movements that I was making on my impulses were becoming redundant. Baron always pointed this out to me, but I could never point out a solution to this habit. I got frustrated with him again, and the preconceived feelings about Baron returned. It also did not help that Baron liked to remind me of things that would put pressure on me: "This is not an easy role." "This role takes a certain muscularity," he would say. "If this was a professional show, you would be fired." Because of the previous productions that I had performed under

${ }^{79}$ Madden, Tyler. My Journal. August 31 
Baron's direction, I was numb to these comments. But the comments never helped me through the process. I was beginning to lose the enjoyment of doing theatre and being a working actor. I was beginning to feel incompetent, which led to doubt about continuing to act after graduate school. I wanted to prove to Baron that I could do the work, because even though he was tough on me he had been my greatest mentor in the program. With all the work that I did with him, I wanted him to see that his time with me was not a waste.

Eventually, I remembered that Baron was going out of town for a week. This gave me a chance to make some progress in rehearsals, but more importantly I wanted to show Baron that I could do this work. Because regardless of how I felt about Baron then, I knew he was not trying to be malicious. He was trying to prepare me. This opened up the opportunity to not only get a break from Baron, but to work with the two people who were monumental in helping me on my ingrained habits: Jenn Calvano, and Rachel Hilmer 


\section{Calvano \& Hilmer: Inhibiting my habits}

During the week that Baron was out of town, Johnny and Baron scheduled for our new movement and voice professors, Dr. Jenn Calvano and Professor Rachel Hilmer, respectively, to come to our rehearsals to work with us. I was currently taking one of Jenn's classes during that semester so I was already beginning to get some guidance from her. I did not have a class with Rachel until the following semester after the production was finished, but I met her when she interviewed for the position during the previous spring semester. She taught a mock class as a part of her interview. I was instantly intrigued when she told us that she was trained in the Alexander technique. Even though I was taught a variety of voice and movement techniques in the graduate program, there was never a solid technique that was being taught in the curriculum or a technique that I was completely confident in. I considered Jenn and Rachel experts in their techniques, which was a big help.

Dr. Calvano, or "Jenn" as she preferred to be called, was grounded in the Grotowski "approach" in acting ${ }^{80}$ Jerzy Grotowski was a Polish theatre director and theorist. His platform in theatre was extended through Konstantin Stanislavski, whose work pioneered modern acting theories. Although his work is derived from Stanislavski's methodological ideas, Grotowski's solutions to acting were different, and at times his work reached conclusions opposite to

${ }^{80}$ Grotowski did not categorize his work as a set of technique, but he looked at his work as a laboratory, or exploration of certain elements. 
Stanislavski's. ${ }^{81}$ Grotowski was concentrated on getting his actors to use physical extremes in order to marry the psychological and physicality of the actor:

Here everything is concentrated on the "ripening" of the actor which is expressed by a tension towards the extreme, by a complete stripping down, by the laying bare of one's own intimity - all this without the least trace of egotisim or self-enjoyment. The actor makes a total gift of himself. ${ }^{82}$

Jenn presented us a variety of Grotowski-based exercises in her movement class. Most of the exercises were physically demanding, but also beneficial for my process. One particular exercise is the Plastiques. The plastique exercise focuses on the details and the articulation of movements emanating from the spine and tracing their way outward towards the periphery of the body. ${ }^{83}$ The exercise required for you to rotate the jointed parts of your body: trunk or torso, the wrist and hand.$^{84}$ According to the compilation text in acting techniques, Actor Training, under the section "Grotowski's Vision of the Actor". author Lisa Wolford only highlights the movement of the trunk, wrist, and the hand. However, when Jenn taught the exercise to us she applied all of the main joints of the body: wrist, hand, knees, shoulders, the head, and feet. The procedure requires a combination of the individual principles in spontaneous dialogue or contact with an acting partner or with some kind of outward stimulus. ${ }^{85}$ The first time Jenn came into rehearsal, she took me into the empty theatre away from the rehearsal space, just myself and her. Jenn made

${ }^{81}$ Grotowski, Jerzy. Towards a Poor Theatre 1991 ed. London, Australia, New Zealand, New York Methuen Drama 1991. Print. (pg.16).

82 Ibid.

${ }^{83}$ Hodge, Alison. Actor Training Second ed. New York, New York USA Routledge

84 Ibid. 2010. Print. (pg.210).

${ }^{85}$ Hodge, pg.210-211. 
me plastique a series of lines from the script. She specifically told me to start with one element or joint at a time. By the time I ended, I was using every joint in my body. The first thing I noticed was that my vocal choices changed instantly; it was not habitual. However, not only was I finding new choices but my diction and the meaning behind the language was clear. This was equivalent to what Grotowski as a director was trying to get out of his actors:

Grotowski elaborated that the process of working with these elements required that the actor begin by fixing and memorizing precise details, then look for the way to transform these details- to make them alive, so that they would become spontaneous and organic, rather than mechanical or calculated - by rediscovering personal impulses within the frame of the codified forms. It was necessary for the actor to be able to combine the elements in different sequences, to change the order and the rhythm, not in a premeditated way, but with the flow dictated by his or her own 'body life. ${ }^{86}$

The more I concentrated on each specific movement, the more I was finding different textures in the dialogue. I was able to find the character psychologically while simultaneously finding him physically within the parameters of the play. After our session, every time I rehearsed a scene I would try to find a way where I could add subtle plastique movements while I was performing. One scene in particular was in act 2 scene 4 where Troy kicks Cory out the house. In this moment of the play, Troy is intoxicated sitting on the steps, blocking Cory from going into the house. Because Troy was intoxicated, I used this moment to rotate my torso and slightly rotate my head without it being noticeable to the audience. The new vocal choices that I found in the language in that scene complemented Troy's drunken behavior that was necessary for the scene. I used this approach all the way from the rehearsal process to the actual performances. The most ${ }^{86}$ Ibid. 
shocking thing to me was how much the movement-based work that I was doing with Jenn would enhance the clarity in my voice. I understood this more when I started to work with Rachel and how the Alexander technique is dependent on how the entire body is in use when you are performing.

Rachel was a certified professor in the Alexander technique. As I said earlier, I was not in her class during the semester of the production, so the work that I was doing with her was a short and accelerated version of the work that I would later do in her class during the following spring semester. An Australian actor named Frederick Mathias Alexander (F.M. Alexander for short) created the technique. Coincidentally, Alexander was an actor who also kept losing his voice during performances. ${ }^{87}$ This was a similar experience to when I blew my voice out during Piano Lesson production at UofL the previous year (Fall 2016). Alexander, a working actor, explored his problems with his voice. Instantly he recognized that he was making physical habits that were a hindrance to his entire body. He was constantly building tension that resorted in the distortion of several primary relationships in the structure of his body. The main physical areas that he discovered that were being affected were the head, neck, and its relationship with the spinal column. ${ }^{88}$ This was intriguing to me, because these physical areas of the body were similar to the operative areas within the plastique exercise. He tried to physically align himself to fix the tension, but he was not successful. Instead, he made it worst because he was compounding his old habits with new habits. He was using the effort to fix the problem in the response of stimulus. He

\footnotetext{
${ }^{87}$ Barbara Adrian, Teresa Lee Movement for Actors New York, New York Allworth Press, 2002. Print. (pg.66)

${ }^{88}$ Ibid.
} 
described this as end-gaining. ${ }^{89}$ Furthermore, he learned that because our habits are unconsciously familiar, we have to be conscious and aware of the whole body. Teresa Lee quotes from F. M. Alexander's The Use of the Self text:

Alexander was able to eventually proceed without the overefforting of his habits by replacing his unconscious habitual thinking with a new conscious constructive thinking process, which he called the means whereby. This process involved mentally letting go of the desire to speak, what he termed inhibition, and redirecting his attention to himself as a whole "in such a way" that he could allow the inherent primary control in his body to be engaged. ${ }^{90}$

This related to my gesturing habits, because I had the impulse to move but I was using the same gestures. Therefore, what Rachel was doing in our one-on-one sessions in combination with the work that I was doing with Jenn was letting me explore the elements in the plastique movements to find new habits. One day, hours before rehearsal, I explored this with Rachel and Jenn. They had me plastique in Rachel's office, but this time I did it going from one line or thought to the next, so I could explore the thought before the line. There was a sensation of my thoughts being aligned with my gesturing, and my body was fully aware of the new changes that I was exploring. This was a huge success for me because I was able to conquer my weakness in voice by using my strength in body. For once, I did not have to overwork myself to seek clarity in my voice. Even though these were expedited lessons, I could instantly feel the difference. When Baron came back, Johnny informed him of the progress I made after those lessons and Baron could see the improvements. Of course, there were certain things he wanted me to do vocally, because of the dynamics in Wilson's text. Wilson has a tendency to have alliteration, consonance, ${ }^{89}$ Ibid.
${ }^{90}$ Ibid. 
punctuation, and other literary and speech devices in his scripts that the actor is required to be aware of when they are performing. For example:

I saw Josh Gibson's daughter yesterday. She walking around with raggedy shoes on her

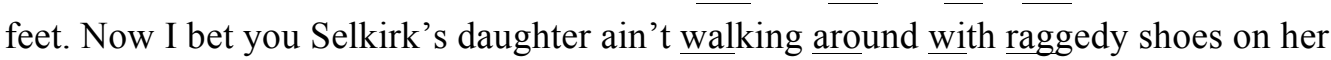
feet! I bet you that! $!^{91}$

In section two, I talked about the different vowel positions in the mouth. If you notice, the words that I highlighted all start with a front vowel, which is placed in the front of the mouth, and they all come after each other. This pattern exists throughout the whole script and usually there is a significant reason for the pattern. The reason that Troy repeats this phrase is because there is antithesis between "Josh Gibson" and "Selkirk." Troy is referring to Negro League baseball Josh Gibson having a disadvantage of being a black baseball player and Selkirk who having the advantage as a white baseball player. He repeats the same phrase "walking around with raggedy shoes on her feet," in a very argumentative tone, which is evident in the exclamation marks at the end of the line. Normally when Wilson is pointing out significant information, it is repeated in the syntax. For example, anytime Troy repeats certain words or phrases towards Cory he is being definitive towards him:

You live in my house ... sleep your behind on my bedclothes . . f fill your belly up with my food ... cause you my son. You my flesh and blood. Not 'cause I like you! Cause it's my duty to take care of you. I owe a responsibility to $y o u !^{92}$

${ }^{91}$ Fences, Pg. 15.

${ }^{92}$ Fences, Pg. 39-40 
Wilson is highlighting the antithesis between "you" and "my." I used this moment to reiterate that my duty as a father was only because he is my son, while simultaneously teaching him to not confuse responsibility with feelings. Imagery played a significant part, in my progress of creating Troy Maxson vocally. This goes back to how Stella Adler speaks of the importance of imagination stemming from the actor she quotes: "The most important thing for the actor is to choose images that evoke an inner feeling." $" 93$ I used certain words that evoked organic images in my subconscious. When Troy talks about when he first moved to Pittsburgh he was homeless. He describes his living conditions: "Living in shacks, made of sticks and tar paper." that came to mind with that line was "dingy, dirty, wet, cold." I started to imagine what that felt like. I was using my images to, transcend the action and the emotion through the lines. Baron also introduced us to an exercise that evoked feelings with certain words as well. He made Paula and I repeat words in the script to spring our inner feelings. One of my words that he had me explore was "Rose." He wanted me to experience the multiple sensations of saying Rose's name.

At first, it was frustrating getting more notes from Baron, but I was able to make the changes consciously without forcing, as F.M. Alexander did when he was having trouble with his voice. Moreover, I started to understand the significance of having Baron in my process. Later on during the rehearsal process, I started to work on the physicality or posture of Troy. I recall from my journal that Jenn reminded me that I should show glimpses of his age instead of being "too constant" about it. Meanwhile, Rachel was working with me on performing with good use within the physical realms of Troy and making sure that I was using the proper alignment for an open channel of breath support. Right before we opened the show after eight weeks of rehearsals,

\footnotetext{
${ }^{93}$ Hodge, Pg. 154

${ }^{94}$ Fences, Pg. 53
} 
Rachel asked me to come to her office for some notes after watching our last rehearsal. She told me that I had definitely improved, but the best advice that she gave me throughout the entire process was "to have fun." After eight weeks, someone finally told me to have fun.

Even though I was appreciative of Rachel's optimistic advice, I was not satisfied until I got over my obstacle of dealing with Baron. I wanted to prove to Baron that I had been taking the work seriously. Therefore, instead of running away from the challenge of working with Baron, I decided to take the initiative and ask him for help on a monologue outside of rehearsal one day. I was going to work on it with or without him, so I decided to ask him for feedback on something that I was working. After that, Baron started to take notice of the effort that I was putting into preparing for show. Finally, the labor was paying off, not because I showed Baron that I could take on the challenge, but because I showed myself that I could. This was the first moment that I felt satisfied in the work that I was doing. 


\section{For the love of Acting: The Performances}

Wednesday, September 21,was the opening night of the production. I started my day differently than I have on any opening night. I came in an hour before my call time because I wanted to prepare early before anyone else came to the theatre. I wanted some alone time. With the work that I had done during rehearsal, I created my own regiment. The first thing I would do was a physical exercise in the theatre: push-ups or running up the stairs in the audience. What inspired this part of my regiment was the "tension towards the extreme" that Grotowksi was trying to get his actors to do. ${ }^{95}$ In addition, the exercising helped me to establish presence that was required of me to play Troy Maxson, not to mention that I had been in class all day and needed to focus my tension. After that, I walked the set to establish familiarity. The set in the Thrust Theatre was the dirt backyard of the Maxsons that extended towards the audience. It is something about actually feeling the texture of the characters' world and living in the realm. Alexander inspired this part of my routine, because it helped me establish what I know now as my "50-50 awareness." In her book The Actor's Secret, Alexander-trained teacher Betsy Polatin defines this term, as "being present with fifty percent of your attention outward and fifty percent of your attention inward." ${ }^{, 96} \mathrm{Next}$, I would get dressed in the dressing room and come back onstage to do a vocal warm-up. My vocal warm-ups were compilations of stressing my consonants, and vowels. I did this by repeating my consonants with the vowels and over articulating them. For example, instead of just over-articulating my consonants, I extended towards my vowels as well. Lastly, I

\footnotetext{
${ }^{95}$ Grotowski, Pg. 16.
}

${ }^{96}$ Polatin, Betsy. The Actors Secret Berkeley, CA North Atlantic Books 2013. Print. (pg. 98) 
went behind the stage to tell the production crew "hello" and I went in the dressing room to give Paula, the actress who played Rose, a hug. These were my and Paula's thesis roles, so it was important for me that I would see her before the show started to wish her luck. I returned to the dressing room, put on my aging makeup, read a couple of my lines and got mentally prepared for the show. How I prepared mentally was different on every night. Some nights I would listen to music that was symbolic to the play. For example, I listened to various R\&B artists from the 1960's to the late 1970's such as Marvin Gaye, The Temptations, and Stevie Wonder. They might not have been the right music for the specific period of the play, but they all had the elements of the blues. Some nights I would sit in a corner by myself outside of the dressing room. Before I knew it, would be time to go out and perform.

The show went by so fast. I did everything that I was supposed to do, according to what we worked on in rehearsals. It was one of the best opening nights that I ever had. Something usually goes wrong, but everything was surprisingly good. The only comment that I can make on that night is that it still felt rehearsed or slightly senseless. Johnny Jones, our assistant director, told me at the end of the week of the run, he felt like that the opening night was the best show in this opinion. If the director said it was a good show, then it was a good show. I think I was a little apprehensive about it, because it was also the first time we had an audience. That added a different element to the process, because the audience is just as much a significant part of the show as the ensemble. Nevertheless, every show was different after that night, but for me the second night (Thursday) was the best.

Thursday started differently for me. First, we had a morning show in addition to the night show we had, which is something that we usually do not do in the program. Our audience was 
high school students from Central High School in Louisville. We started the show around 10 a.m. Even though it was early, I was still accustomed to performing in the morning because the previous year I was a part of our repertory company, where we performed shows for young audiences in various elementary and middle schools around Louisville. The difference between those shows and Fences is the length and the content of the show. The repertory shows were 30 minutes apiece and Fences was a two-and-a-half hour show with two acts. Instead of presenting a message to kids about caring for one another, I was doing a show where I was pretending to be a man who drinks gin on Friday nights and talks about "stroking" his wife in bed. Unfortunately, this ended up not being the best show, and I think we all knew it. Part of the problem for me was that it felt like we were too dependent on the audience. They were high school students, and many of them had never been to the theatre. In addition to that, the majority of the kids were black so the language of the show was recognizable, particularly with the word "nigger." The content made the kids react in multiple ways; some of the kids laughed and made a big deal about us saying the word. I had to remind myself that I have to go back to depending on the work from the rehearsal process. The kids still loved the show and cheered.

After the show, I went to class as I normally do. When it was time for the night show, I started once again with my warm-up routine, coming in an hour early. Even though I was feeling relaxed, I still felt like something was missing in my performance, and that was finding the personal connection with the play, particularly with the dynamic of Troy and Rose's marriage. I knew Troy and Rose was married for 18 years, so I thought about moments in my life that I could relate to within an 18-year time span. This was my attempt on using the substitution method in the rehearsal process. Unfortunately, I had no success in my search for a direct connection with 
Troy being married for 18 years. Nevertheless, I remembered having a conversation with Baron and Johnny about looking into the people who were close to me who were married for a long time. The first person I thought about was my father. My father, Ron Corbett, had ended his second marriage two years before I started Fences; he was married to my stepmom Denean, for 26 years. I grew up watching their marriage from a distance, because I was living with my mother. I was there to watch the rise and decline of their marriage. I vividly remembered watching my father struggle emotionally when my stepmom abruptly left him. My father had a lot of pride, and he tried to conceal his feelings, but my siblings and I knew that he was not emotionally well during this time. This became a model for me on marriage. I used the same void that my stepmom and my dad had right before they got divorced, and substituted it with the void that Troy and Rose had after Rose found out about Troy's infidelity. Baron encouraged that throughout the process I should find some parallels between Troy and me to help build the character. Out of all the parallel connections that I have found throughout this play the most direct connection was with Raynell, Troy's illegitimate daughter. I was an illegitimate child. My father was engaged by the time he conceived me, and by the time I was born, he and Denean were married. When Raynell was born, Rose took it upon herself to take care of Raynell as her own even after Troy's death. Denean may not have raised me, but she treated me like her own. This entire realization happened before the show even started. That moment reminded me why I was in love with acting all over again. It is because of the revelations that I get from every show. From the time the show started to the time it ended, I was full with the spirit of Troy Maxson. Finally, I had everything I needed to play Troy. I had the techniques, I had the audience, and most importantly, I had the connection. The most iconic moment was in Act 2 Scene 4, which is the last scene before Troy dies. In this scene, Troy gets in a fight with Cory and ends up kicking him 
out of the house. When I got offstage at the end of the scene I abruptly started to cry, not because my personal feelings from earlier, but because I actually felt overly empathetic with what took place in this scene. One of the most important conventions that I value in acting is the element of storytelling, and after that day and through the entire run of the show I felt like I successfully told a story. While I was trying to prove to Baron that I was capable of doing this role, I simultaneously proved it to another familiar critic, Keith Waits of the Louisville Courier-Journal:

Tyler Madden's Troy is his MFA thesis role, and he shows greater discipline than his previous work in The Piano Lesson. He still has the fiery drive and sense of integrity in the character, and he brings great flavor to Troy. Madden is half the age of the man he plays, which is a challenge, but he suggests the weariness and desperation of Troy without, mercifully, the need for pronounced make-up effects. ${ }^{97}$

When the show was over, I came offstage to greet some of the audience members. Some of them were other students from the program, and one of them was my other classmate and best friend Shaleen. When I came out, Shaleen ran up to me, hugged me, and said he was proud of me. This was significant because we came in together and worked to get to this point in our craft. Other students came up to me and congratulated me as well.

Later on, I was sitting in the office talking and joking with some fellow actors that I worked with in the past about the work. I had suddenly answered my question about finding the happiness in the labor. It was this moment where I realized that in order to enjoy the work, you must do the work leading up to the moments so you can enjoy the product. I was having a good time because I survived the work that I did leading up to now. It is similar to why Troy drinks on Friday nights, because it was the celebration of getting through a week's worth of work.

${ }^{97}$ Waits, ---. "One Man’s Salvation." (2016). Print 
Furthermore, Troy knew he deserved it because when he pulled that money out that was the result of the work. This is why I entitled this chapter, "Enjoying the Fruits of your Labor". During the semester in Jenn's movement class, she talked about process versus product. This inspired me to think about how we set ourselves up for failure because we are always trying to be perfect without enjoying the progress that we have already made. I still had more performances after that night, so the work was never done. However, the process should always be going no matter what, because the moment you stop is when you stop growing as an artist. The milestones or the key moment of progress throughout the journey is what should keep you happy. The sessions that I had with Rachel and Jenn were a milestone, because I had finally found an approach that works for me. Was I perfect in this show? No, I was not and that is okay because none of us are. 


\title{
$6(\& 7,21 \square), 9(\square$
}

\author{
\&2 $1 \& / 86,210$ \\ "... That's the way that go!",98
}

\section{How will I enjoy the Work}

Acting throughout my career has taught me many lessons, but the best lesson has been within the journey. I am 29 years old. For some, that is old, but it is not for my professors who are older than me. So when professors like Baron Kelly are critical of my work, it was not because he was perfect or because he knew everything. It was simply because he had been in the process of acting longer than I have. My father once told me, "You never stop learning no matter how old you are." He is right. Either I learn from someone else or I can take the initiative to learn on my own. What I have learned from this process is that some goals must be achieved over a span of time. Now that does not mean that I am going to sit around while I wait for something to come my way. No, I have to work. One day I was writing in my journal after I had class with Jenn about process versus product:

When we talked about process, it made me think about everything I do in life. Everyday should be a process. It's always a process for us. It's like learning. We learn everyday, all of us. But the question is, "are we processing it"? We'll never be the perfect product, but if you allow yourself to change during the process, then something will be produced overtime.

${ }^{98}$ Fences, Pg.93. 
The operative word in that quote is change because it is a word that brings action. You must be doing something; you have to be working. One of Baron's favorite sayings, in his signature voice, is “Ahh, you're working!!” He helped me realize that the work never stops. I looked up to Baron, because he works all the time. Majority of the time that I see him, he is always working on something. For example, during most of the runs of the show I did not see Baron around as much as usual. The reason was that he was busy preparing for the next show of the season, William Shakespeare's Lear. Not only was he acting in the show, but he was the lead, King Lear. This is a tenured professor who is the head of acting in the program directing one of August Wilson's iconic plays and in the middle of his own process preparing for Lear. That was something that I admired about Baron, but I always felt intimidated by his dynamic work ethic until now. Because of the work that I have done in Fences, I realized that it takes time to gain that type of work ethic. In the meantime, I will work to allow change in my process and celebrate the progress along the way. The future is already in progress, because I am still working on me. The next semester after Fences, I took one of Rachel's voice classes to further my work in Alexander. I grew even more after taking her class, as I was able to articulate the Alexander work that I applied to the thesis role. I do wish I would have been able to take her class during the production of Fences, but I will not allow any regrets to hinder the growth that I have made in the show. This brings me to another lesson that I learned. If you fall short on the work, just learn from your mistakes and move on. Because I have the tools and techniques for acting, I am confident in my ability to do the work but most importantly as long as I have the initiative to do the work then I will be fine. You can enjoy the fruits of your labor, but you cannot enjoy them without the labor. 
When Troy was being vocal about his job being prejudiced and not allowing the colored workers to drive the trucks, his initiative worked in his favor and he ended up being the first colored driver. Before I started writing this conclusive chapter, I was standing outside getting some air trying to figure out how to end it. While I was thinking, I noticed the garbage truck was coming down my road and the sanitation workers were picking up the trash. As the truck got closer, everything came full circle for me: I saw two white men come off the back of the truck to pick up the trash and to my surprise, a black man was driving the truck. Recognizing and admiring the progress is how you enjoy the fruits of your labor. 


\section{5()$(5(1 \&(6 \square$}

New Oxford American Dictionary: Oxford University Press, Inc, 2010, 2016. Print.

Conversations with August Wilson. University Press of Mississippi 2006. Print.

"Fair Labor Standards Act Advisor ". Ed. Labor, United States Department of. Washington, DC Print.

"Wilson’s “Four B’s"." (2015). Print.

Barbara Adrian, Teresa Lee Movement for Actors New York, New York Allworth Press, 2002. Print.

Beşe, Ahmet. "The Significance of the Blues as a Cultural Expression in Ma Rainey's Black Bottom." Ma Rainey's Black Bottom'da Blues Müziğin Kültürel İfade Biçimi Olarak Anlamı. 15.1 (2011): 227-34. Print.

Bogumil, Mary L. Understanding August Wilson Revised ed. Columbia, SC USA University of South Carolina Press 2011. Print.

Clark, Keith. Black Manhood in James Baldwin, Ernest J. Gaines, and August Wilson Univesity of Illinois, USA University of Illinois 2002 Print.

Cohen, Robert. Acting One/ Acting Two 5th ed. New York, NY McGraw-Hill/ Chris Freitag 2008. Print.

Grotowski, Jerzy. Towards a Poor Theatre 1991 ed. London, Australia, New Zealand, New York Methuen Drama 1991. Print.

Hagen, Uta. Respect for Acting New York John Wiley \& Sons, Inc 1973, 2008. Print.

Hodge, Alison. Actor Training Second ed. New York, New York USA Routledge 2010. Print.

Kenneth L. Stilson, Larry D. Clark, Charles McGaw Acting Is Believing 12th ed. Stamford, CT Cengage Learning 2015, 2012, 2009. Print.

Macey, David. Dictionary of Critical Theory New York, New York Penguin Group 2000. Print. Madden, Tyler. My Journal

Olson, Jon. "Procrastination." Surface Fabrication. Feb 14.2 (2008): 20. Print. 
Reich, Steven A. A Working People. Lanham, Maryland Rowman \& Littlefield 2013 Print.

Relph, Patricia. Movement for the Actor Ed. Rubin, Lucille S. 1st ed. New York, New York Drama Book Specialists 1980. Print.

Robinson, Rachel. "Jackie Robinson." Essence (Essence) 27.7 (1996): 52. Print.

Schwartzman, David. Black Unemployment: Part of Unskilled Unemployment Westport, CT USA Greenwood Press 1997. Print.

Waits, Keith. "Not the Lesson You Imagine." Arts-Louisville (2015). Web. 2015-11-19.

---. "One Man’s Salvation." (2016). Print.

Wilson, August. Fences 1986 ed. New York, New York U.S.A. : Samuel French, 1986. Print. 
\&8 55,\&8/ $80[9,7 \$ \square$

NAME:

ADDRESS:

DOB:

EDUCATION

\& TRAINING:
Tyler Reid Madden

Theatre Arts Department

2314 S. Floyd St.

University of Louisville

Louisville, KY 40208

Greensboro, North Carolina - June 15, 1987 